\title{
Dissolved organic carbon (DOC) and select aldehydes in cloud and fog water: the role of the aqueous phase in impacting trace gas budgets
}

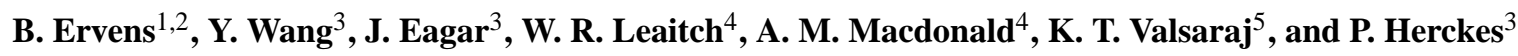 \\ ${ }^{1}$ Cooperative Institute for Research in Environmental Sciences, University of Colorado, Boulder, Colorado, USA \\ ${ }^{2}$ Chemical Sciences Division, NOAA Earth System Research Laboratory, Boulder, Colorado, USA \\ ${ }^{3}$ Arizona State University, Department of Chemistry and Biochemistry, Arizona, USA \\ ${ }^{4}$ Air Quality Research Division, Atmospheric Science and Technology Directorate, Science and Technology Branch, \\ Environment Canada, Downsview, Canada \\ ${ }^{5}$ Cain Department of Chemical Engineering, Louisiana State University, Baton Rouge, LA, USA \\ Correspondence to: B. Ervens (barbara.ervens @ noaa.gov) and P. Herckes (pierre.herckes@asu.edu)
}

Received: 29 October 2012 - Published in Atmos. Chem. Phys. Discuss.: 19 December 2012

Revised: 9 April 2013 - Accepted: 20 April 2013 - Published: 21 May 2013

\begin{abstract}
Cloud and fog droplets efficiently scavenge and process water-soluble compounds and, thus, modify the chemical composition of the gas and particle phases. The concentrations of dissolved organic carbon (DOC) in the aqueous phase reach concentrations on the order of $\sim 10 \mathrm{mgC} \mathrm{L}^{-1}$ which is typically on the same order of magnitude as the sum of inorganic anions. Aldehydes and carboxylic acids typically comprise a large fraction of DOC because of their high solubility. The dissolution of species in the aqueous phase can lead to (i) the removal of species from the gas phase preventing their processing by gas phase reactions (e.g., photolysis of aldehydes) and (ii) the formation of unique products that do not have any efficient gas phase sources (e.g., dicarboxylic acids).

We present measurements of DOC and select aldehydes in fog water at high elevation and intercepted clouds at a biogenically-impacted location (Whistler, Canada) and in fog water in a more polluted area (Davis, CA). Concentrations of formaldehyde, glyoxal and methylglyoxal were in the micromolar range and comprised $\leq 2 \%$ each individually of the DOC. Comparison of the DOC and aldehyde concentrations to those at other locations shows good agreement and reveals highest levels for both in anthropogenically impacted regions. Based on this overview, we conclude that the fraction of organic carbon (dissolved and insoluble inclusions) in the aqueous phase of clouds or fogs, respectively, com-
\end{abstract}

prises $2-\sim 40 \%$ of total organic carbon. Higher values are observed to be associated with aged air masses where organics are expected to be more highly oxidised and, thus, more soluble. Accordingly, the aqueous/gas partitioning ratio expressed here as an effective Henry's law constant for DOC $\left(K_{\mathrm{H}}{ }^{* \mathrm{DOC}}\right)$ increases by an order of magnitude from $7 \times 10^{3} \mathrm{M} \mathrm{atm}^{-1}$ to $7 \times 10^{4} \mathrm{M} \mathrm{atm}^{-1}$ during the ageing of air masses.

The measurements are accompanied by photochemical box model simulations. These simulations are used to contrast two scenarios, i.e., an anthropogenically vs. a more biogenically impacted one as being representative for Davis and Whistler, respectively. Since the simplicity of the box model prevents a fully quantitative prediction of the observed aldehyde concentrations, we rather use the model results to compare trends in aldehyde partitioning and ratios. They suggest that the scavenging of aldehydes by the aqueous phase can reduce $\mathrm{HO}_{2}$ gas phase levels significantly by two orders of magnitude due to a weaker net source of $\mathrm{HO}_{2}$ production from aldehyde photolysis in the gas phase. Despite the high solubility of dicarbonyl compounds (glyoxal, methylglyoxal), their impact on the $\mathrm{HO}_{2}$ budget by scavenging is $<10 \%$ of that of formaldehyde. The overview of DOC and aldehyde measurements presented here reveals that clouds and fogs can be efficient sinks for organics, with increasing importance in aged air masses. Even though aldehydes, 
specifically formaldehyde, only comprise $\sim 1 \%$ of DOC, their scavenging and processing in the aqueous phase might translate into significant effects in the oxidation capacity of the atmosphere.

\section{Introduction}

The aqueous phase of clouds and fog constitutes a small volume of the atmosphere $\left(\sim 10^{-7}\right.$ vol vol $\left.^{-1}\right)$, but can act as an efficient reservoir and reactor to convert soluble trace gases. Such soluble compounds include oxidation products of volatile organic compounds (VOC) that are emitted from anthropogenic or biogenic sources and are ubiquitous in the atmosphere. The most abundant organic compounds that have been identified in cloud and fog droplets are small volatile carboxylic acids (e.g., formic and acetic acids) as well as C1-C3 carbonyl compounds (Herckes et al., 2002b; Collett Jr. et al., 2008). Formaldehyde represents an end product in the oxidation chain of numerous VOCs and its gas phase mixing ratio exceeds that of other aldehydes by a factor up to 10 (Munger et al., 1995). However, difunctional aldehydes, such as glyoxal or methylglyoxal, have higher Henry's law constants than formaldehyde (by a factor of 10-100) resulting in similar aqueous phase concentrations as formaldehyde (e.g., Igawa et al., 1989; Munger et al., 1989). Simultaneous gas and cloud or fog water measurements have shown that such highly soluble, small aldehydes are nearly in thermodynamic equilibrium whereas the aqueous phase appears to be enriched in larger compounds ( $\geq \mathrm{C} 4$ ) by up to a factor of 1000 (Munger et al., 1995; van Pinxteren et al., 2005; Li et al., 2008). The dissolved aldehyde fractions scale with the amount of total scavenged material that is removed by clouds and precipitation (Limbeck and Puxbaum, 2000; Maria and Russell, 2005; Li et al., 2008; Gong et al., 2011).

Oxidative processing of mono- and difunctional aldehydes in the aqueous phase leads to the formation of carboxylic acids that contribute to the acidity of rain water in remote regions (Khare et al., 1999). While the contributions of aqueous phase reactions to the total budgets of formic and acetic acids are not well constrained, it is established that aqueous phase processes represent the main source of keto- and dicarboxylic acids (Warneck, 2005). Many recent model, laboratory and field studies explored the role of aqueous phase reactions for the formation of such multifunctional acids since they remain in the particle phase upon droplet evaporation and contribute to ambient secondary organic aerosol (SOA) mass (e.g., Lim et al., 2010; Ervens et al., 2011; Lee et al., 2011). Less work has been dedicated to assessing the role of the aqueous phase of clouds and fogs as a reservoir of dissolved organic carbon (DOC) and specifically aldehydes by evaluating their aqueous/gas partitioning.
One of the most important net sources of the $\mathrm{HO}_{2}$ radical in the atmosphere is the photolysis of formaldehyde in the gas phase (Finlayson-Pitts and Pitts, 2000):

$$
\begin{aligned}
& \mathrm{HCHO}+\mathrm{h} v\left(+\mathrm{O}_{2}\right) \rightarrow \mathrm{HO}_{2}+\mathrm{CHO} \\
& \mathrm{CHO}+\mathrm{O}_{2} \rightarrow \mathrm{HO}_{2}+\mathrm{CO}
\end{aligned}
$$

The photolysis of other aldehydes such as glyoxal and methylglyoxal also yields $\mathrm{CHO}$ and, thus, leads to the formation of $\mathrm{HO}_{2}$ by Reaction (R3), followed by (R2).

$\mathrm{RCHO}+\mathrm{h} v\left(+\mathrm{O}_{2}\right) \rightarrow \mathrm{RO}_{2}+\mathrm{CHO}$

Further reaction of the organic peroxy radical $\mathrm{RO}_{2}$ eventually results in $\mathrm{HCHO}$; however, during this process $\mathrm{HO}_{2}$ is consumed (R4) which leads to a net $\mathrm{HO}_{2}$ yield of unity from Reactions (R4) and (R5). Additional loss processes of the peroxides $\mathrm{ROOH}$ even decrease further this $\mathrm{HO}_{2}(\mathrm{~g})$ yield from $\mathrm{RCHO}$.

$$
\begin{aligned}
& \mathrm{RO}_{2}+\mathrm{HO}_{2} \rightarrow \mathrm{ROOH} \\
& \mathrm{ROOH}+\mathrm{O}_{2} \rightarrow \rightarrow \mathrm{HCHO}
\end{aligned}
$$

In the aqueous phase aldehydes are (partially) hydrated and form the diol

$$
\mathrm{RCHO}(\mathrm{aq})+\mathrm{H}_{2} \mathrm{O} \rightleftarrows \mathrm{RCH}(\mathrm{OH})_{2}(\mathrm{aq})
$$

In the aqueous phase, the interaction of polar functional groups (e.g., carbonyl) with water molecules causes significant differences in their reactivity in gas and aqueous phases, respectively: While in the gas phase, oxidation and/or photolysis products of carbonyl compounds usually comprise small radicals from carbon-carbon bond breakage (R3), hydration effects in the aqueous phase prevent such fragmentation and lead to functionalisation of the reactants under retention of the carbon structure (e.g., carboxylic acid formation from aldehydes). There is evidence from a series of recent laboratory studies that carbonyl compounds might be also partially hydrated in the gas phase (Axson et al., 2010; Maron et al., 2011). Due to the lack of observational data, this effect cannot be explored by means of model studies yet. Since hydrated aldehyde (diol) groups do not undergo significant photolysis at atmospherically-relevant wavelengths, dissolved aldehydes that are present in their hydrated form are not efficient net $\mathrm{HO}_{\mathrm{x}}$ sources.

In addition to the gas aldehydes' role as net $\mathrm{HO}_{\mathrm{x}}$ source, their different reactivities in gas and aqueous phases have further impacts on the $\mathrm{HO}_{x}$ cycle: the rates of the $\mathrm{OH}$ reactions with dissolved aldehydes and their diols are usually higher than those of the corresponding gas phase aldehydes which can lead to an efficient removal of $\mathrm{OH}$ upon uptake into droplets (Monod et al., 2005). Assuming day time $\mathrm{OH}$ concentrations of $\sim 10^{6} \mathrm{~cm}^{-3}$ and $10^{-13} \mathrm{M}$ in the gas and aqueous phases, respectively, the first order loss rates for aldehydes $\left(k^{1 \mathrm{st}}=k^{2 \mathrm{nd}}[\mathrm{OH}]\right)$ are on the order of $10^{-5} \mathrm{~s}^{-1}$ 
$\left(10^{-11} \mathrm{~cm}^{3} \mathrm{~s}^{-1} \times 10^{6} \mathrm{~cm}^{-3}\right)$ and $10^{-4} \mathrm{~s}^{-1}\left(\sim 10^{9} \mathrm{M}^{-1} \mathrm{~s}^{-1}\right.$ $\left.\times 10^{-13} \mathrm{M}\right)$, respectively. Indeed, it has been shown that the oxidation of hydrated formaldehyde by $\mathrm{OH}$ (and other organics) in cloud water is the main sink of dissolved $\mathrm{OH}$ in cloud droplets (Ervens et al., 2003a) and significantly contributes to the observed decrease in $\mathrm{OH}$ and other oxidant concentrations during cloud events (Frost et al., 1999; Morita et al., 2004). However, while Reactions (R1) through (R5) impact the absolute $\mathrm{HO}_{\mathrm{x}}$ budget, the faster $\mathrm{OH}$ reactions in the aqueous phase also yield $\mathrm{HO}_{2}$ and accelerate the $\mathrm{OH}-$ $\mathrm{HO}_{2}$ turnover. Based on that, it has been shown that the uptake of formaldehyde (which is present up to $\sim 99 \%$ in its diol form at atmospherically-relevant temperatures, Betterton and Hoffmann, 1988) into cloud droplets might have a sensitive impact on the atmospheric $\mathrm{HO}_{\mathrm{x}}$ budget (Lelieveld and Crutzen, 1991); the role of other aldehydes (e.g., glyoxal, methylglyoxal) has not been explored yet.

In the current study, we present aqueous phase measurements of DOC and specific aldehydes (formaldehyde, glyoxal, and methylglyoxal) at two different locations: (1) Cloud and fog water was collected in Whistler (British Columbia, Canada), which represents a location that is impacted by a mix of anthropogenic and biogenic emissions. (2) Fog water was sampled in Davis (California), where the anthropogenic emissions were higher than in Whistler. These two datasets are discussed in the broader context of DOC and aldehyde concentrations and gas/aqueous partitioning at other locations that represent a wide spectrum of locations and emissions. Box model studies are performed to reproduce trends and ratios of the observed aldehyde levels in the aqueous phase. While we do not attempt to simulate cloud/fog processing of aldehydes in detail, we rather apply the model to contrast aldehyde levels in two scenarios (Whistler vs. Davis) that differ in aldehyde precursors and cloud/fog liquid water content. Based on additional, more exploratory simulations, the effects of aldehyde removal by uptake and aqueous phase processing on gas-phase oxidant $\left(\mathrm{HO}_{2}\right)$ levels are estimated.

\section{Experimental methods}

\subsection{Sampling locations}

The "Whistler Aerosol and Cloud Study" (WACS2010) was conducted between 22 June and 28 July 2010 on Whistler Mountain, Whistler, British Columbia, Canada and aimed at exploring the interactions of biogenic emissions with clouds in a coniferous forest area. Chemical and microphysical measurements of the aerosol, gas and cloud phases were performed at mid-mountain (Raven's Nest, $1300 \mathrm{~m}$ a.s.l.) and at the Whistler Peak (2182 m a.s.1.). Lidar measurements were conducted at mountain base ( $665 \mathrm{~m}$ a.s.1.). Overall conditions and detailed information on measurements are provided elsewhere (Lee et al., 2011; Pierce et al., 2012; Ahlm et al., 2013). A total of eight cloud events were sampled at Raven's
Nest and three at the Peak site, some longer events yielded several cloud samples. Temperatures during the cloud events were within $\sim 10 \pm 5^{\circ} \mathrm{C}$.

The second sampling location was in Davis, CA where a radiation fog field study was conducted between 6 January 2011 and 26 January 2011. Six fog events were sampled at the agricultural research station of the University of California, Davis. Average temperatures were in the range of $\sim 3-$ $10^{\circ} \mathrm{C}$. Emissions in the wintertime are mainly impacted by vehicle traffic, biomass burning for heating purposes as well as some agricultural activities. More detailed information on the site, trace gas measurements and meteorological parameters is provided by Ehrenhauser et al. (2012).

\subsection{Measurements}

\subsubsection{Liquid water content}

In Whistler, cloud water samples were collected at Whistler Peak (Mountain peak site) and at the Raven's Nest site (midmountain site) using an automated version of the Caltech Active Strand Cloud Water Collector (CASCC) (Demoz et al., 1996; Hutchings et al., 2009). Cloud Liquid Water Content (LWC) was measured using a Gerber Particulate Volume Monitor (Gerber PVM 100) (Gerber, 1991). The PVM data was used to trigger automated sampling.

In Davis, several CASCC type collectors were used for fogwater collection (e.g., Ehrenhauser et al., 2012). A Colorado State University Optical Fog Detector CSU-OFD was used (Carrillo et al., 2008) to trigger fog collection and provide semi-quantitative data. The obtained data could be used to assess relative trends in LWC and for detection purposes while absolute LWC values were inaccurate. LWC ranges used as input to the model simulations (Sect. 4) were derived from the volume of the collected fog samples, accounting for the collection efficiency (Ehrenhauser et al., 2012).

\subsubsection{Chemical analysis of cloud and fog water samples}

Identical methods to analyse the water samples were applied at both locations and followed protocols and methodologies used previously (e.g., Collett Jr. et al., 2008; Hutchings et al., 2009) with the exception of mass spectrometric analyses for aldehydes as detailed below. Collected aqueous samples were weighed to determine collected water mass, then aliquotted for different chemical analyses. Fog or cloud sample $\mathrm{pH}$ was measured on site with a Denver Instruments IB-5 pH meter equipped with a Fisher Scientific Accumet gelfilled $\mathrm{pH}$ electrode, calibrated against $\mathrm{pH} 4$ and 7 buffers.

Sample aliquots for dissolved organic carbon (DOC) analysis and aldehyde analysis were filtered through pre-fired glass fiber filters (VWR North America \#691, $1.5 \mu \mathrm{m}$ pore size) in the field and stored in pre-baked amber glassware with a Teflon lined septa caps. The samples were stored refrigerated, and analysis was performed immediately after 
completion of the field study. Both filtration and refrigerated storage minimised possible microbial activity in the samples. DOC concentrations were determined using a Shimadzu total organic carbon (TOC) analyser (TOC-5000A) which was calibrated against potassium hydrogen phthalate standards. An aliquot of $30 \mathrm{~mL}$ of filtered cloud or fog water was preserved for aldehyde analysis by derivatisation in the field immediately upon collection. Final sample extracts were analysed using a Varian Prostar 210 HPLC system coupled to a Varian 335 Diode Array UV-Vis detector followed by a Varian $1200 \mathrm{~L}$ triple quadrupole mass spectrometric detector. Compound separation was performed using a Supelcosil LC18 $(25 \mathrm{~cm} \times 3 \mathrm{~mm} \times 5 \mu \mathrm{m})$ column and gradient elution. Instrument and mass spectrometer-specific parameters are detailed in Tables S1 and S2 in the Supplement.

After each fog collection event and between events, if no event occurred for several days, the cloud collectors were abundantly rinsed with deionised (DI) water and field blanks were taken by nebulising DI water into the collector inlet with the sampler running. Cleaning prevented any contamination by dry deposition and blanks allowed for the detection of any particulate contamination. Major ion blanks were mostly below detection limits and if detected, concentrations were very low compared to measured concentrations (e.g., $1 \mu \mathrm{N}$ for nitrate). For TOC, typical blank values were $1 \mathrm{mgC} \mathrm{L}^{-1}$ or less; however, transport blanks for the DI water used for cleaning (transport and storage in the field) yielded similar values. For aldehydes and volatile organics, the fact that the blanks are obtained by nebulising DI water in the field into the collector like fog droplets results automatically in partitioning of gas phase species into the blanks during collection of the blank. Therefore, highly soluble and abundant gas phase species like formaldehyde are detected in these field blanks, but typically at much lower levels than concentrations in fog/cloud water as the exposure time often does not allow for equilibrium partitioning. No blank subtractions were performed. Duplicate analyses were typically within $5 \%$ of each other for TOC, ions and formaldehyde and around $15 \%$ for dicarbonyl compounds.

\subsection{Box model description}

\subsubsection{Chemical mechanism}

A photochemical box model is applied to simulate partitioning and processing of three aldehydes (formaldehyde, glyoxal, methylglyoxal) over short time scales that either correspond to drop lifetimes in orographic clouds, or processing times in more convective clouds (Whistler) or to typical settling times of droplets in fog (Davis). The formation of glyoxal and methylglyoxal is described by the gas phase oxidation of isoprene, toluene, benzene, xylene, based on the NCAR Master Mechanism (Madronich and Calvert, 1990; Stroud et al., 2003). Organics are oxidised by $\mathrm{OH}$ and ozone. Photolysis rates are adjusted to the respective locations and time of day (morning hours); it is assumed that photolysis rates are not affected by the presence of clouds/fog which might represent an overestimate of the photolysis rates in the interstitial spaces of optically thick clouds or their underestimate in the interstitial spaces in optically thin regions (Mayer et al., 1998; Tie et al., 2003). The aqueous phase oxidation mechanism of glyoxal and methylglyoxal has been used in previous model studies (Tables 1-3 in Ervens et al., 2004). In the aqueous phase, organic oxidation only occurs by the $\mathrm{OH}$ radical as it has been shown that contributions of other radicals are minor (Ervens et al., 2003a). As compared to more detailed multiphase models (e.g., Ervens et al., 2003a), concentrations of $\mathrm{OH}(\mathrm{aq})$ might be underestimated since we only include uptake from the gas phase as its only source and neglect any Fenton-type reactions. However, on the other hand, the total organics' concentration in the aqueous phase is also likely to be underestimated, since the considered aldehydes only represent a small fraction of all dissolved organics (cf. Sect. 3.2) that likely represent a significant sink for $\mathrm{OH}(\mathrm{aq})$. While such inferred bias in simulated $\mathrm{OH}(\mathrm{aq})$ might affect absolute predicted aldehyde concentrations, trends in concentration ratios are not significantly biased. As opposed to the prior study by Ervens et al. (2004), we only use aromatics (benzene, toluene) and isoprene as precursors for gas phase dicarbonyl compounds and do not initialise ethylene and cyclohexene. The formation of formaldehyde is not explicitly simulated since primary sources of formaldehyde might be substantial and cannot be easily quantified (Lin et al., 2012). Instead, we initialise it in the gas phase and include its uptake to the droplets and its sinks reactions in both the aqueous and gas phases. The initial conditions for the box model are summarised in Table 1. These concentrations are held constant over the course of the simulations since it is assumed that they are continuously replenished.

\subsubsection{Gas/aqueous phase interactions}

Unlike in previous model studies that addressed microphysical processes (e.g., cloud formation and evolution) in more detail (e.g., Ervens et al., 2004), in the current study, these processes are neglected and the total liquid water content (LWC) is distributed to a monodisperse drop population with a drop diameter of $10 \mu \mathrm{m}$. Constant interaction between the gas and aqueous phases and chemical reactions in both phases are assumed for the whole simulation time ( $t \leq 1.3 \mathrm{~h}$ for clouds (Whistler); $t \leq 5 \mathrm{~h}$ for fog (Davis)). Simulations are performed for a range of liquid water contents $\left(0.05 \mathrm{~g} \mathrm{~m}^{-3}<\mathrm{LWC}<0.3 \mathrm{~g} \mathrm{~m}^{-3}\right)$. This LWC range covers the observed, highly variable LWCs in Whistler and Davis (Fig. 1). We assume constant temperatures for the two cases, i.e., $T=7^{\circ} \mathrm{C}$ in the Davis scenario (Ehrenhauser et al., 2012), and $T=10^{\circ} \mathrm{C}$ in the Whistler one.

Since the model does not include any microphysical description of cloud (fog) evolution and precipitation, it cannot give detailed results in terms of the impact of the aqueous 
Table 1. Initial mixing ratios $[\mathrm{ppb}]$ for the two scenarios as considered in the box model simulations.

\begin{tabular}{lrr}
\hline & $\begin{array}{c}\text { Whistler } \\
\text { This study }\end{array}$ & $\begin{array}{r}\text { Davis } \\
\text { Ehrenhauser et al. (2012) }\end{array}$ \\
\hline Isoprene & 0.6 & 0.2 \\
Benzene & 0.05 & 2 \\
Toluene & 0.1 & 4 \\
$\mathrm{O}_{3}$ & 25 & 70 \\
$\mathrm{NO}_{\mathrm{x}}$ & 4 & 20 \\
$\mathrm{CO}$ & 120 & 500 \\
$\mathrm{HCHO}$ & 1 & 1 \\
$\mathrm{H}_{2} \mathrm{O}_{2}$ & 0.2 & 0.2 \\
\hline
\end{tabular}

phase on the wet scavenging and removal of organic trace gases (e.g., Blando and Turpin, 2000; Yin et al., 2001; van Pinxteren et al., 2005). In order to constrain processing times of aldehydes within the limitation of the box model, we took into account the different types of aqueous phases (clouds/fogs) at the two locations: Cloud/air interaction times in orographic clouds can be constrained by flux measurements (Colvile et al., 1996). In general, wind velocities in these clouds in Whistler were low and clouds with orographic components resembled static radiation fog that lasted for $0.5 \mathrm{~h}-\sim 1 \mathrm{~h}$. Most of the clouds exhibited characteristics of cumulus/stratocumulus clouds with average thickness of $\sim 600 \mathrm{~m}( \pm 200 \mathrm{~m}$, at Raven's Nest) with somewhat shallower and more convective clouds at the Peak. While the drop lifetime in such convective clouds is limited to a few minutes, it is likely that particles cycle multiple times through the clouds and, thus, the total processing time might be a multiple of the drop lifetime. Based on the evolution of aerosol composition (sulfate increase), it can be concluded that each particle might have undergone about three cloud cycles. In summary, we estimate that particles in the cloud (fog) water in Whistler (both at the Peak site and Raven's Nest) are processed for a few minutes up to about $80 \mathrm{~min}$. In radiation fog as encountered in Davis, droplet lifetime is controlled by the settling velocity of droplets. Typical fog thickness varied from $<20 \mathrm{~m}$ to $\sim 250 \mathrm{~m}$ (Holets and Swanson, 1981). Since droplets can be formed at any height in the fog, the average fall height of a droplet is about half of the fog thickness. With a settling velocity of $0.68 \mathrm{~cm} \mathrm{~s}^{-1}$ for a $15 \mu \mathrm{m}$ droplet (Noone et al., 1992; Seinfeld and Pandis, 1998), the range of droplet lifetime can be calculated as $\sim 0.5-5 \mathrm{~h}$. Of course, this lifetime is might vary by more than a factor of two for (less abundant) smaller or larger droplets and for droplets that form closer to fog bottom or top.

Beyond these meteorological effects that limit drop lifetimes and, thus, processing times, physicochemical characteristics of aldehydes make it even harder to give accurate estimates of processing times. For aqueous phase formation of non-volatile products (e.g., sulfate or secondary organic aerosol), it is reasonable to assume that continuous interac-
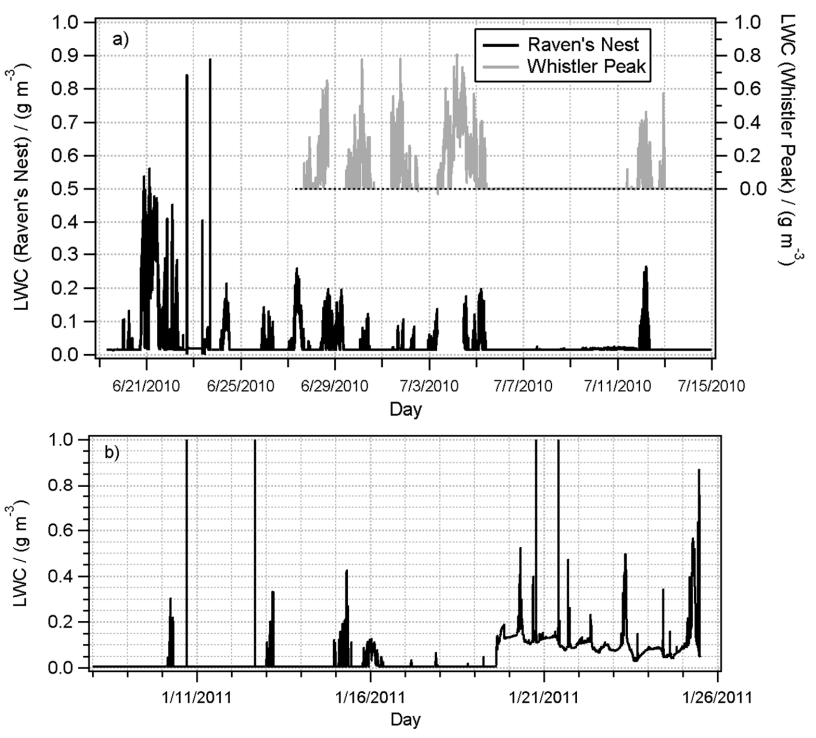

Fig. 1. Temporal evolution of liquid water content (LWC) (a) in Whistler (fog/intercepted clouds) at Raven's Nest and Whistler Peak, measured with Gerber PVM and (b) in radiation fog in Davis measured with a CSU-OFD.

tions of the aqueous phase with the surrounding gas phase might be representative for multiple cloud cycles during which mass will accumulate (Sorooshian et al., 2006). However, the situation is more complex for highly soluble and volatile compounds (e.g., aldehydes) since (1) time scales of gas uptake to reach equilibrium are inversely proportional to droplet sizes and equilibration time scales might exceed the lifetime of droplets (Finlayson-Pitts and Pitts, 2000; Ervens et al., 2003a), and (2) aldehydes might not completely accumulate during multiple cloud cycles in convective clouds since they are volatile and (partially) evaporate together with water. However, several recent studies suggest that the fraction of carbonyl compounds in the aqueous phase of deliquesced particles as present upon drop evaporation is greater by several orders of magnitude than predicted by Henry's law constants (e.g., Baboukas et al., 2000; Healy et al., 2009; Volkamer et al., 2009). While these studies show that the assumption of Henry's law constants is not appropriate to represent partitioning in deliquesced particles, the reasons for this deviation are not fully clear and, thus, cannot be assessed in models. In summary, the ranges of processing time in our model studies should be considered as being approximate. However, the ratios of the aldehyde aqueous phase concentrations should be still meaningful in order to contrast the two scenarios as guided by the data acquired in Whistler and Davis and to explore effects on predicted $\mathrm{HO}_{2}$ concentrations in these two emission scenarios. 


\section{Results and discussion}

\subsection{Fog and cloud occurrence}

The clouds sampled at Whistler Peak contained significantly more water ( $\mathrm{LWC} \leq 1 \mathrm{~g} \mathrm{~m}^{-3}$ ) than the fogs in Davis where the average LWC was $<0.1 \mathrm{~g} \mathrm{~m}^{-3}$ (0.019$0.086 \mathrm{~g} \mathrm{~m}^{-3}$ based on the collected volumes of water; Fig. 1), in general agreement with the higher cloud LWC as compared to fogs (Seinfeld and Pandis, 1998). In Davis, for part of the study, the optical fog detector yielded qualitative data (detection of fog events) rather than quantitative data (Ehrenhauser et al., 2012). In Whistler, cloud samples were collected both at day and at night time. The local topography with upslope/downslope winds made it impossible to clearly differentiate between intercepted (strato)cumulus clouds with orographic components. One sample obtained at Whistler Peak (evening to morning), and seven samples from Raven's Nest were prepared for carbonyl analysis, four of which were collected during daylight while three were collected during partial day and partial night time. The sampling times ranged from 1.25 to $15 \mathrm{~h}$; most were less than two hours. The typical duration of cloud events on the order of two hours was similar to observations during winter at the same location (Mo et al., 2012).

In Davis, radiation fogs typically formed in the evening or at night and lasted through the morning hours although one event persisted throughout the day at low LWC (Ehrenhauser et al., 2012). Eight of the samples were analysed for carbonyl compounds - of which four were night samples, three were daylight samples and one was an evening sample. The corresponding sampling times varied from 2.5 to $8 \mathrm{~h}$.

\subsection{Dissolved organic carbon (DOC)}

The DOC concentrations in the Whistler cloud study ranged from 1.8 to $5.8 \mathrm{mgC} \mathrm{L}^{-1}$ at Raven's Nest and 3.1$8.1 \mathrm{mgC} \mathrm{L}^{-1}$ at the Peak site (Fig. 2a). Except for the 11 July event which showed a very high DOC concentration at the Peak, all concentrations were similar at the Peak site and at Raven's Nest. The DOC concentrations in the radiation fogs in Davis were generally higher than in Whistler and ranged from 5.9 to $27 \mathrm{mgC} \mathrm{L}^{-1}$ with a median value of $12.6 \mathrm{mgC} \mathrm{L}^{-1}$ (Fig. 2b). In general, DOC concentrations reflect the abundance of VOCs and carbonaceous particles in the atmosphere and, thus, as expected the observed levels in Whistler are in the lower range of observed concentrations in continental clouds (Table 2; Fig. 2c). Although the atmosphere at Whistler can contain substantial concentrations of VOCs and organic aerosol, they are largely from biogenic sources and consequently strong functions of temperature (e.g., Leaitch et al., 2010); during 2010, the clouds sampled were mostly during cooler periods when biogenic emissions might have been partially suppressed.
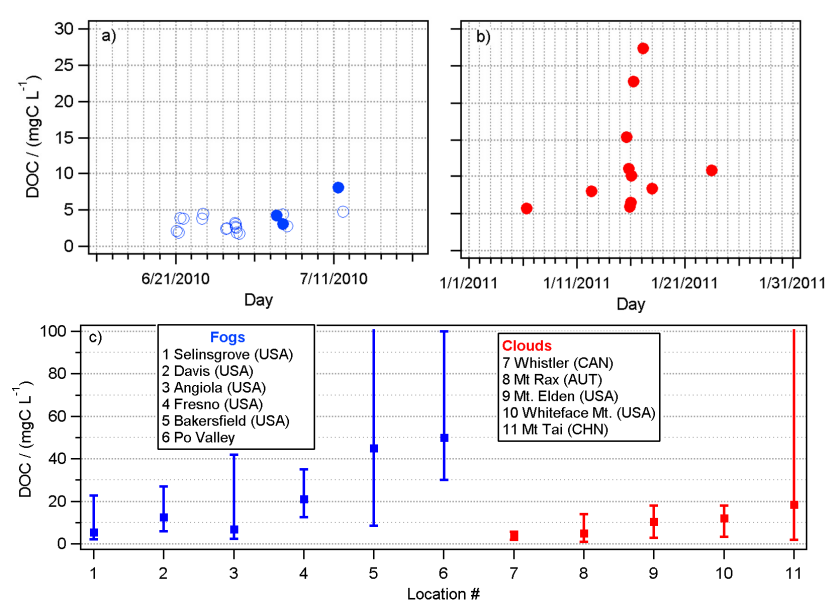

Fig. 2. Time series of dissolved organic carbon (DOC) concentrations in (a) Whistler cloud water (Open symbols correspond to samples from Raven's Nest site while full symbols represent samples from the Peak site) and (b) Davis fog water; (c) select DOC concentrations in fogs and clouds at several locations. (1) All-year mesurements (Straub et al., 2012); (2) 01/2011, this study; (3) winter (Herckes et al., 2007); (4) 01/2011 (Ehrenhauser et al., 2012); (5) 01/1983 (Jacob et al., 1984); (6) no dates reported (Fuzzi and Zappoli, 1996); (7) 06-07/2010, this study; (8) 04/1999; 03/2000 (Loeflund et al., 2002); (9) 07/2005; 08/2006, 09/2006, 08/2007, 10/2007 (Hutchings et al., 2009); (10) 08/1990, 07/1991, 08/1991, 06-08/1992 (Anastasio et al., 1994); (11) 03-07/2007 (Wang et al., 2011). Symbols represent median values, lines represent the range of values (min-max).

Figure 2c summarises DOC levels in cloud and fog water from previous studies at various locations and shows that the present observations fall within the spread of the concentrations reported. DOC sampled in fog water in Davis was at the lower end of observations in the Central Valley of California with a median higher than in rural Angiola, but clearly lower than in the larger urban areas of Fresno and Bakersfield. The concentrations were slightly higher than observations in rural Pennsylvania, but lower compared to Po Valley studies. DOC concentrations in Whistler were on the lower end for reported cloud observations. DOC was lower than in more polluted environments including the US East Coast, Europe or China. The highest DOC values in Whistler $\left(\sim 10 \mathrm{mgC} \mathrm{L}^{-1}\right)$ are higher than the average values in the more anthropogenically-impacted locations possibly because of stronger biogenic organic carbon sources in Whistler. In general, it has been found that DOC constitutes about $80 \%$ of the total organic carbon (TOC) in the aqueous phase (Herckes et al., 2002a; Raja et al., 2008; Straub et al., 2012); thus, DOC is a nearly quantitative measure of TOC in the condensed phase of clouds and fogs.

In order to estimate the fraction of DOC to the total organic carbon (i.e., in gas and condensed phases), a measure is needed that quantifies total organic carbon in the atmosphere. 
Table 2. Overview of measured liquid water content (LWC) and dissolved organic carbon (DOC) concentrations at various locations. The ambient DOC mass concentrations $\left(\mathrm{DOC}_{\mathrm{m}}\left[\mu \mathrm{gC} \mathrm{m} \mathrm{m}^{-3}\right]\right.$ ) are a product of the measured DOC concentrations $\left[\mathrm{mgC} \mathrm{L}^{-1}\right]$ and $\mathrm{LWC}$ The TOOC values are estimated as for locations of similar pollution levels, based on the listed $\mathrm{OC}_{\mathrm{p}}$ concentrations and a compilation by Heald et al. (2008). The fraction of organic carbon in the aqueous phase $\mathrm{F}\left(\mathrm{OC}_{\mathrm{aq}}\right)$ represents the ratio of $\mathrm{DOC}_{\mathrm{m}}$ and TOOC. The derived effective Henry's law constant for organic carbon $K_{\mathrm{H}}^{* \mathrm{DOC}}$ is the ratio of DOC and OC in the gas phase (TOOC - DOC), i.e., it describes the partitioning of total $\mathrm{OC}$ between the gas and aqueous phases.

\begin{tabular}{|c|c|c|c|c|c|c|c|c|}
\hline \multirow[b]{2}{*}{ Location } & \multicolumn{3}{|c|}{ Measured data } & \multirow[b]{2}{*}{ Reference } & \multicolumn{4}{|c|}{ Calculated parameters } \\
\hline & $\begin{array}{l}\mathrm{LWC} \\
\mathrm{g} \mathrm{m}^{-3}\end{array}$ & $\begin{array}{l}\text { DOC } \\
\mathrm{mgCL}_{\mathrm{aq}}{ }^{-1}\end{array}$ & $\begin{array}{l}\mathrm{OC}_{\mathrm{p}} \\
\mu \mathrm{gC} \mathrm{m}^{-3}\end{array}$ & & $\begin{array}{l}\mathrm{DOC}_{m} \\
\mu \mathrm{gC} \mathrm{m} \\
-3\end{array}$ & $\begin{array}{l}\text { TOOC } \\
\mu \mathrm{gC} \mathrm{m}^{-3}\end{array}$ & $\begin{array}{l}\mathrm{F}\left(\mathrm{OC}_{\mathrm{aq}}\right) \\
{[\%]}\end{array}$ & $\begin{array}{l}K_{\mathrm{H}}^{* \mathrm{DOC}} \\
10^{4} \mathrm{Matm}^{-1}\end{array}$ \\
\hline Fresno, CA & 0.14 & 15.0 & 7.0 & $\begin{array}{l}\text { LWC/DOC: (Collett Jr. } \\
\text { et al., 2008); OC: esti- } \\
\text { mated based on Chow } \\
\text { et al. (2006) }\end{array}$ & 2.1 & 73.3 & $3 \%$ & 0.9 \\
\hline Mount Tai (China) & 0.25 & 18.5 & 5.5 & $\begin{array}{l}\text { LWC: Guo et al. } \\
\text { (2012); DOC: (Wang et } \\
\text { al., 2011); OC: Wang et } \\
\text { al. (2012) }\end{array}$ & 4.6 & 44.8 & $10 \%$ & 1.9 \\
\hline Davis, CA & 0.08 & 12.5 & 3.7 & This study & 1.0 & 30.1 & $3 \%$ & 1.8 \\
\hline Houston, TX & 0.065 & 10.4 & 3.2 & $\begin{array}{l}\text { LWC/DOC: Raja et al. } \\
(2009) \text {; DOC average } \\
\text { from Fraser et al. } \\
(2002)\end{array}$ & 0.68 & 26.1 & $3 \%$ & 1.7 \\
\hline Whistler (Canada) & 0.15 & 3.4 & 2.6 & This study & 0.51 & 21.0 & $2 \%$ & 0.7 \\
\hline Angiola, CA & $0.21^{1}$ & 6.9 & 2.5 & $\begin{array}{l}\text { LWC/DOC (Herckes et } \\
\text { al., 2007); OC } \\
\text { estimated based on } \\
\text { Chow et al. (2006) }\end{array}$ & 1.5 & 20.4 & $7 \%$ & 1.5 \\
\hline Baton Rouge, LA & 0.08 & 5.3 & 2.4 & $\begin{array}{l}\text { LWC/DOC: Raja et al. } \\
\text { (2009); } \\
\text { annual mean from } \\
\text { IMPROVE CSM }\end{array}$ & 1.6 & 19.5 & $2 \%$ & 1.2 \\
\hline Schmücke (Germany) ${ }^{2}$ & 0.27 & 5.8 & 1.8 & $\begin{array}{l}\text { Brüggemann et al. } \\
\text { (2005) }\end{array}$ & 0.42 & 15.0 & $11 \%$ & 2.0 \\
\hline Mount Rax (Austria) & 0.28 & 6.02 & 1.3 & Bauer et al. (2002) & 1.7 & 10.2 & $17 \%$ & 2.9 \\
\hline Whiteface Mountain, NY & 0.49 & 7.6 & 1 & $\begin{array}{l}\text { LWC/DOC: Khwaja et } \\
\text { al. (1995); OC: } \\
\text { estimated based on } \\
\text { Schwab et al. (2004) }\end{array}$ & 3.7 & 8.1 & $46 \%$ & 7.1 \\
\hline
\end{tabular}

${ }^{1}$ Unpublished LWC value.

2 Average of three cloud events.

A comprehensive summary of the ambient total observed organic carbon (TOOC) (gas and particulate; no clouds) over North America is given by Heald et al. (2008): concentrations reach from $\sim 5 \mu \mathrm{gC} \mathrm{m} \mathrm{m}^{-3}$ in remote areas (Trinidad Head) to $>40 \mu g \mathrm{C} \mathrm{m}^{-3}$ in large cities (e.g., Pittsburgh and Mexico City). TOOC excludes methane and includes all other organic carbon that can be detected by standard techniques. Comparison of the sum of individual organics and the total organic carbon revealed deviations of $15-45 \%$ in aged air masses. This difference was ascribed to semivolatile, multifunctional oxidation products that cannot be detected by available techniques. The analysis by Heald et al. (2008) reveals that small compounds $\left(\leq \mathrm{C}_{3}\right)$ that are easily accessible by routine measurements contribute to a significant fraction of all measured organics and, thus, TOOC likely captures the major fraction of the total organic carbon that is present in the atmosphere. The ratio of aerosol to gas phase $\mathrm{OC}\left(\mathrm{OC}_{\mathrm{p}} / \mathrm{OC}_{\mathrm{gas}}\right)$ varies from $\sim 6-46 \%$ with a median value of $14 \%$ (Fig. 6a in Heald et al., 2008). Based on this median ratio, the fraction of $\mathrm{OC}$ that is associated with the particle phase can be calculated as $\mathrm{F}\left(\mathrm{OC}_{\mathrm{p}}\right)=\mathrm{OC}_{\mathrm{p}} /\left(\mathrm{OC}_{\mathrm{p}}+\mathrm{OC}_{\mathrm{gas}}\right)$ $=12.3 \%(0.14 / 1.14 \times 100 \%)$ whereas the denominator represents TOOC. Since $\mathrm{F}\left(\mathrm{OC}_{\mathrm{p}}\right)$ is not directly available from the measurements listed in Table 2, we estimate TOOC based on $\mathrm{OC}_{\mathrm{p}}$ measurements and assume

$\operatorname{TOOC}\left[\mu \mathrm{gCm}^{-3}\right]=\frac{\mathrm{OC}_{\mathrm{p}}\left[\mu \mathrm{gCm} \mathrm{m}^{-3}\right]}{12.3 \%} \cdot 100 \%$

Using these TOOC values, the ratio of the aqueous (DOC) and gas phase concentrations can be derived. We express the ratio in the following as an overall effective Henry's law 
constant for DOC

$K_{\mathrm{H}}^{* \mathrm{DOC}}=\frac{\mathrm{DOC}\left[\mathrm{molL}_{\mathrm{aq}}^{-1}\right]}{\mathrm{OC}_{\mathrm{gas}}[\mathrm{atm}]}$

$K_{\mathrm{H}}^{* \mathrm{DOC}}$ describes the partitioning of total OC, i.e., it does not refer to the gas/aqueous equilibrium of individual compounds, but includes all organic compounds that are present in the aqueous phase (either dissolved from condensation nuclei or taken up from the gas phase) and gas phase organics. Details on the calculation are given in the Supplement. Given that DOC represents the major fraction of all organic carbon in the aqueous phase, $K_{\mathrm{H}}^{* \mathrm{DOC}}$ can be considered an approximate measure of the partitioning of TOC between the condensed phases of cloud/fog water and the gas phase.

The resulting range of $7000<K_{\mathrm{H}}^{* \mathrm{DOC}}\left[\mathrm{M} \mathrm{atm}^{-1}\right]<71000$ is in general agreement with Henry's law constants for monofunctional compounds, such as formaldehyde $\left(K_{\mathrm{H}}[\mathrm{M}\right.$ $\left.\mathrm{atm}^{-1}\right]=2970 \times[7216 \times \exp (1 / T[\mathrm{~K}]-1 / 298)]$, Betterton and Hoffmann, 1988) or formic acid $\left(K_{\mathrm{H}}\left[\mathrm{M} \mathrm{atm}^{-1}\right]\right.$ $=3700 \times \exp [5700 \times \exp (1 / T[\mathrm{~K}]-1 / 298)]$; at $\mathrm{pH}=4$, Chameides, 1984) which might support the general finding that species with such functional groups might comprise a significant fraction of DOC. However, they are much lower than the value that has been derived for gas/particle partitioning of water-soluble organic carbon $\left([\mathrm{WSOC}]_{\mathrm{aq}} / p_{\mathrm{WSOC}}=\right.$ $K_{\mathrm{H}}^{* \mathrm{WSOC}} \sim 2 \times 10^{9} \mathrm{M} \mathrm{atm}^{-1}$, Hennigan et al., 2009) in the absence of clouds. This trend is in agreement with results for the gas/particle partitioning of individual highly polar compounds that show significantly greater particulate fractions than predicted based on Henry's law constants (Baboukas et al., 2000; Matsunaga et al., 2005; Healy et al., 2008; Liu et al., 2012).

Based on $K_{\mathrm{H}}^{* \mathrm{DOC}}$, the fraction of organic carbon can be derived, dissolved in the aqueous phase of cloud/fog droplets $\left(\mathrm{F}\left(\mathrm{OC}_{\mathrm{aq}}\right)\right)$, which is defined in the following as

$\mathrm{F}\left(\mathrm{OC}_{\mathrm{aq}}\right)=\operatorname{DOC}\left[\mu \mathrm{gCm}{ }^{-3}\right] / \mathrm{TOOC}\left[\mu \mathrm{gCm}^{-3}\right] \cdot 100 \%$

These values show that the organic carbon fraction dissolved in cloud water is $\sim 1-46 \%$ depending on location (Table 2). This estimate implies that the aqueous phase of clouds/fog is the only condensed phase in the considered volume of the atmosphere. While often a major fraction of particles (diameters $<\sim 100 \mathrm{~nm}$ ) do not activate into droplets, the total mass of these particles comprises only a minor fraction of total condensed phase mass. Thus, we expect the bias by neglecting insoluble particulate organic mass in Eq. (3) to be small.

The amount of water associated with non-activated particles (in interstitial spaces or in the absence of clouds) is smaller by several orders of magnitude than that of cloud droplets (LWC(particles) $\sim 10 \mu \mathrm{g} \mathrm{m}^{-3}$ vs. LWC(clouds) $\sim 0.1 \mathrm{~g} \mathrm{~m}^{-3}$ ). In such particles, the volume of the water phase might be comparable to that of (an) organic phase(s) where less water-soluble, more hydrophobic organics might be absorbed. Thus, particulate mass does not necessarily correlate with the particle LWC. In clouds, the aqueous phase represents by far the largest condensed phase and, thus, the fraction of DOC exceeds that of all other organics. While it is likely that a large fraction of particulate organic carbon is dissolved in droplets that formed on organic condensation nuclei, $\mathrm{F}\left(\mathrm{OC}_{\mathrm{aq}}\right)$ may also be enhanced by dissolution of soluble organic gases too volatile to be associated with particles outside of clouds/fogs. While we have used an average value of $14 \%$ for $\mathrm{OC}_{\mathrm{p}} / \mathrm{TOOC}$, in the original study this value shows considerable variability (6-32\%) (Heald et al., 2008). The lowest value $(6 \%$ ) was observed in Pittsburgh where $66 \%$ of the organic aerosol fraction was classified as oxygenated organic aerosol (OOA) and can be considered as water-soluble (Zhang et al., 2005). The maximum value was derived in more aged air masses at Chebogue Point where the organic aerosol fraction was nearly completely oxygenated (Ervens et al., 2007). OOA is usually associated with accumulation mode particles that can be activated into droplets where water-soluble constituents will dissolve. Thus, it is expected that most of the particulate organic carbon will dissolve in activated droplets. Comparison of the range of particulate organic carbon fraction $\left(\sim 6 \%<\mathrm{F}\left(\mathrm{OC}_{\mathrm{p}}\right)<32 \%\right.$, Heald et al., 2008) and the data derived in Table $2\left(2 \%<\mathrm{F}\left(\mathrm{OC}_{\mathrm{aq}}\right)\right.$ $<46 \%$ ) suggests that a major fraction of DOC in clouds/fog originates from dissolved particles and a minor fraction of DOC is comprised of dissolved (volatile) gases with increasing contributions in aged air masses.

The data in Table 2 are sorted by the $\mathrm{OC}_{\mathrm{p}}$ mass concentration, as a proxy for pollution level. The majority of the locations listed in Table 2 are impacted by anthropogenic emissions. However, the relatively high $\mathrm{OC}_{\mathrm{p}}$ in Whistler is mostly due to freshly-emitted biogenic compounds. Despite the uncertainty associated with the estimate in TOOC, the fractions and $K_{\mathrm{H}}^{* \mathrm{DOC}}$ values in Table 2 show a trend with decreasing particulate $\mathrm{OC}$ mass. $\mathrm{F}\left(\mathrm{OC}_{\mathrm{aq}}\right)$ is relatively low at Fresno, $\mathrm{CA}$, where highly polluted radiation fog was sampled. Organics were not aged and, thus, their solubility was limited (reflected by the relatively low $K_{\mathrm{H}}^{* \mathrm{DOC}}=7000 \mathrm{M} \mathrm{atm}^{-1}$ ). Locations with lower $\mathrm{OC}_{\mathrm{p}}$ concentrations generally show higher organic fractions in the aqueous phase. This trend can be explained by the fact that fresh air masses are usually diluted during transport leading to lower $\mathrm{OC}_{\mathrm{p}}$ loadings. During transport and ageing, organics become oxidised which translates into higher solubility which in turn leads to higher dissolved fractions. The highest $\mathrm{F}\left(\mathrm{OC}_{\mathrm{aq}}\right)$ values are estimated to have been present in clouds at Whiteface Mountain. While the LWC was highest among all locations listed in Table 2, this factor alone cannot account for the significantly higher fraction of organics that is dissolved (46\%). The higher solubility associated with more aged air masses is also reflected in the trend of $K_{\mathrm{H}}^{* \mathrm{DOC}}$ (Eq. 2; and Supplement) as it increases from $K_{\mathrm{H}}^{* \mathrm{DOC}}<10000 \mathrm{M} \mathrm{atm}^{-1}$ for the fresh air masses in Fresno and Whistler to $K_{\mathrm{H}}^{\mathrm{DOC}}=71000 \mathrm{M} \mathrm{atm}^{-1}$ in the most 

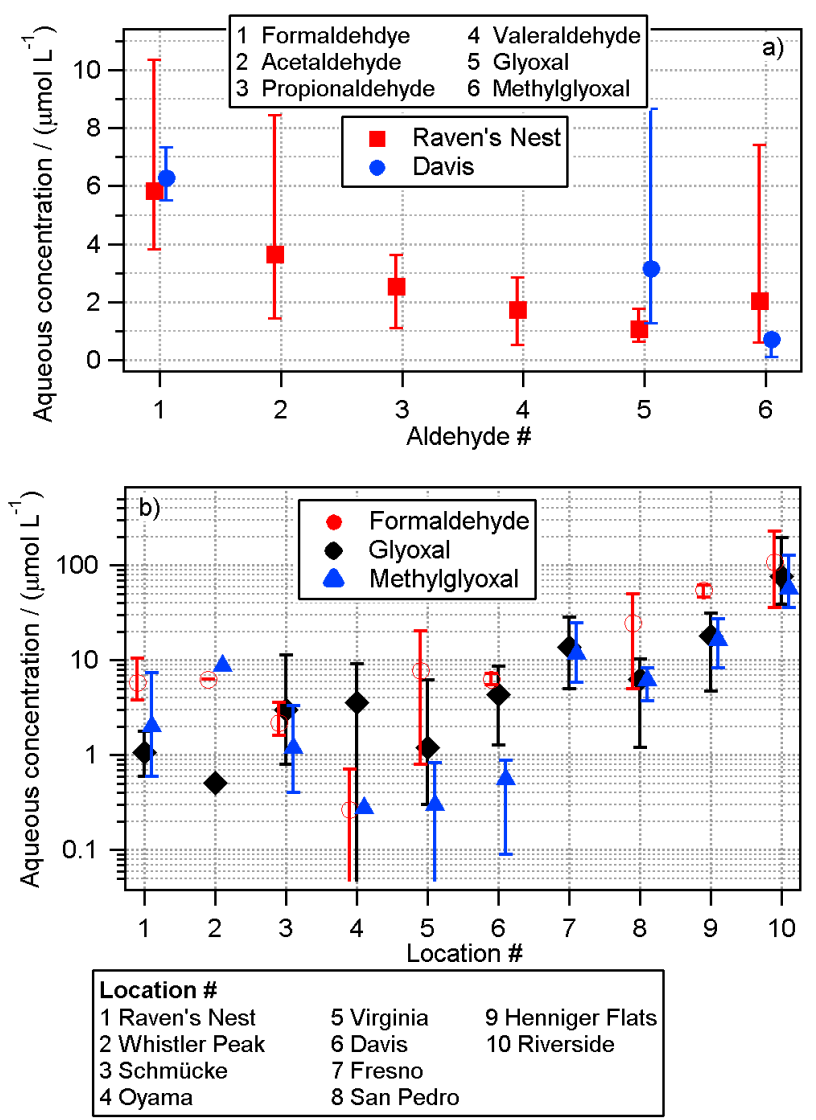

Fig. 3. (a) Measured aldehyde concentrations in cloud (Raven's Nest) and fog water (Davis); (b) comparison to formaldehyde, glyoxal and methylglyoxal concentrations at various locations: 1 . and 2.: 06-07/2010, this study; 3.: 10/2010, and 10/2011; van Pinxteren et al. (2005); 4.: all-year measurements 2003; Matsumoto et al. (2005); 5.: 09/1990; Munger et al. (1995); 6: 01/2011, this study; 7.: 12/2003-01/2004 (Youngster, 2005); 8. and 9.: 06/1987, 01-03/1986 Igawa et al. (1989); 10.: Igawa et al. (1989) Symbols represent median values, lines represent the range of values (min$\max$.

aged air masses at Whiteface Mountain. Similar trends have been observed for the degree of oxygenation of organic aerosol particles that usually show enhanced amounts of highly oxidised material in aged air masses whereas the ageing can occur either in the gas or aqueous phase (e.g., $\mathrm{Ng}$ et al., 2011).

\subsection{Aldehydes in cloud and fog water}

\subsubsection{Aqueous phase concentrations and their ratios}

Figure 3a shows the concentrations of individual aldehydes observed during the two studies. In Whistler, the sum of all aldehyde concentrations included in this study ranges from 12 to $25 \mu \mathrm{M}$ at Raven's Nest (Whistler). The most abundant aldehyde was formaldehyde which ranged from 3.8-
10.4 $\mu \mathrm{M}$. Formaldehyde was followed by acetaldehyde, propionaldehyde and valeraldehyde. Glyoxal and methylglyoxal concentrations were typically lower than formaldehyde and acetaldehyde, but still on the same order of magnitude. The four carbonyl and two dicarbonyl compounds contribute each about $2-3 \%$ to the identified DOC on average. In Davis, the dataset is limited to formaldehyde, glyoxal and methylglyoxal. Formaldehyde was typically the most abundant aldehyde with concentrations from 5.5 to $7.3 \mu \mathrm{M}$. Concentrations of glyoxal were more variable $(1.3-8.7 \mu \mathrm{M})$. Methylglyoxal concentrations were lower with concentrations of $0.1-0.9 \mu \mathrm{M}$. Overall these aldehydes contribute $<1 \%$ to the identified DOC in Davis. This trend is agreement with the findings from Table 2 that imply a smaller contribution of highly soluble species, such as aldehydes, to DOC.

Figure 3b compares the observed aldehyde concentrations in Whistler and Davis to corresponding measurements at other locations. In agreement with higher VOC emissions in more polluted scenarios, the aldehyde concentrations differ by more than two orders of magnitude between the most polluted (Riverside) and the most remote location (Whistler), whereas the latter was characterised by relatively higher biogenic emissions. For any given location, the aqueous phase concentrations are mostly within the same order of magnitude for the three aldehydes despite their greatly different gas phase levels (not measured in Whistler and Davis): in Virginia, median formaldehyde levels of $755 \mathrm{ppt}$ were found and significantly smaller glyoxal and methylglyoxal mixing ratios (22 ppt, $<50$ ppt, respectively) (Munger et al., 1995). At the Schmücke (Germany), formaldehyde, glyoxal and methylglyoxal mean mixing ratios ranged from 480940 ppt, 1-23 ppt, and 17-75 ppt, respectively, depending on time of day and wind direction (Müller et al., 2005). The Henry's law constants of glyoxal and methylglyoxal are approximately two and one order of magnitude higher than that of formaldehyde, respectively: $K_{\mathrm{H} \text {, Glyoxal }}\left[\mathrm{M} \mathrm{atm}^{-1}\right]$ $=4.19 \times 10^{5} \times \exp [(62200 / R) \times(1 / T[\mathrm{~K}]-1 / 298)](\mathrm{Ip}$ et al., 2009); $K_{\mathrm{H}, \text { Methylglyoxal }}=32000 \mathrm{M} \mathrm{atm}^{-1}$ (in sea water, Zhou and Mopper, 1990) for which likely a similar temperature dependence can be assumed as for the other aldehydes and as for methylglyoxal in pure water $\left(\Delta H_{\text {sol }}\right.$ $=-62700 \mathrm{~kJ} \mathrm{~mol}^{-1}$, Betterton and Hoffmann, 1988); and $K_{\mathrm{H}, \text { Formaldehyde }}=2970 \times \exp [(59800 / R) \times(1 / T[\mathrm{~K}]-$ 1/298)] $\mathrm{M} \mathrm{atm}^{-1}$ (Betterton and Hoffmann, 1988). Assuming thermodynamic equilibrium, these differences in solubility result in predicted dissolved fractions of $50 \%, 5 \%$ and $\sim 1 \%$ for the three aldehydes for an $\mathrm{LWC}=0.1 \mathrm{~g} \mathrm{~m}^{-3}$ (Fig. 4), whereas the resulting aqueous phase concentrations of all three aldehydes are on the same order of magnitude (Fig. 3).

The total concentration levels of the aldehydes depend on the precursor mixtures which are vastly different between anthropogenic (e.g., Riverside) and more biogenicallyimpacted (e.g., Whistler) locations. While the glyoxal and methylglyoxal yields from toluene are approximately equal $\left(24 \%\right.$ and $19 \%$, respectively, at low $\mathrm{NO}_{\mathrm{x}}$ level), 


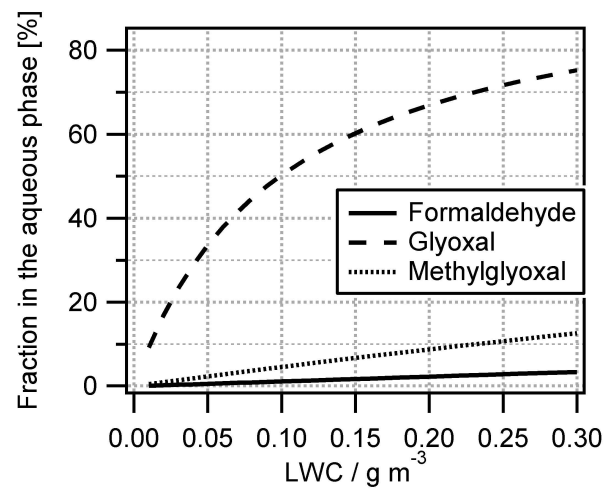

Fig. 4. Predicted dissolved aldehyde fraction in the aqueous phase as a function of liquid water content, assuming thermodynamic equilibrium and effective Henry's law constants (including hydration).

methylglyoxal yields from o- and m-xylene exceed the ones of glyoxal by a factor of $\sim 4(\sim 10 \%$ and $\sim 40 \%$, respectively) (Nishino et al., 2010). Glyoxal and methylglyoxal are not only first, but also second-generation products in the oxidation of isoprene and, thus, their concentration ratio changes over time depending on the availability of oxidants. In general, the overall yields of these aldehydes from isoprene are much more uncertain, but in general to be expected lower than those from the oxidation of aromatics $(<\sim 2 \%$ glyoxal yield, $\sim 20 \%$ methylglyoxal yield from isoprene, Galloway et al., 2011). Whistler is the location that is more strongly impacted by biogenic emissions as compared to Davis, thus, the main glyoxal and methylglyoxal precursor is expected to be isoprene. The photolysis rates and second-order rate constants for the $\mathrm{OH}$ reactions in the gas phase differ by less than a factor of two for both difunctional compounds, respectively $\left(j_{\mathrm{Gly}}=8 \times 10^{-5} \mathrm{~s}^{-1} ; j_{\mathrm{Mgly}}=1.2 \times 10^{-4} \mathrm{~s}^{-1}\right.$ (based on the TUV model by Tie et al., 2003); $k_{\mathrm{OH}, \mathrm{Gly}}=1.15 \times 10^{-11} \mathrm{~cm}^{3}$ $\mathrm{s}^{-1} ; k_{\mathrm{OH}, \mathrm{Mgly}}=1.75 \times 10^{-11} \mathrm{~cm}^{3} \mathrm{~s}^{-1}$, Plum et al., 1983). In the aqueous phase, the ratio of the second-order rate constants for the $\mathrm{OH}$ reactions of both dicarbonyl compounds is similar $\left(k_{\mathrm{OH}, \mathrm{Gly}}=1.1 \times 10^{9} \mathrm{M}^{-1} \mathrm{~s}^{-1}\right.$ (Buxton et al., 1997); $k_{\mathrm{OH}}, \mathrm{Mgly}=6.2 \times 10^{8} \mathrm{M}^{-1} \mathrm{~s}^{-1}$, Schaefer et al., 2012). Thus, the loss terms of the aldehydes are similar when they are exposed to identical air masses. The differences in the concentration ratios of glyoxal to methylglyoxal in the aqueous phase (less than unity in Whistler, greater than unity at all other locations, Fig. 3b) can be explained by the higher methylglyoxal yields from isoprene as compared to glyoxal. In addition, in more aged air masses the more soluble glyoxal might have been preferentially removed by scavenging and processing in the condensed phase.

\subsubsection{Gas/aqueous phase partitioning of aldehydes}

There are only a few datasets available that report simultaneous measurements of aldehydes in both phases, gas and aqueous. In orographic clouds at the Schmücke (Germany), it was found that the partitioning of formaldehyde, glyoxal and methylglyoxal between the aqueous and gas phases corresponds to [Aldehyde] $]_{\mathrm{aq}} / p_{\text {Aldehyde }}=\sim 3000 \mathrm{M} \mathrm{atm}^{-1}$; $\sim 2 \times 10^{5} \mathrm{M} \mathrm{atm}^{-1}$ and $3 \times 10^{4} \mathrm{M} \mathrm{atm}^{-1}$, respectively (van Pinxteren et al., 2005). Similar ratios can be also calculated for the partitioning of these compounds observed in Virginia (Munger et al., 1995) and for formaldehyde during the ICARTT campaign ( $\mathrm{Li}$ et al., 2008). These ratios are very close (within factors of $\sim 0.7, \sim 2$, and $\sim 3$ ) to the Henry's law constants at $298 \mathrm{~K}\left(K_{\mathrm{H}, 298 \mathrm{~K}}(\right.$ Glyoxal $)=$ $4.19 \times 10^{5} \mathrm{M} \mathrm{atm}^{-1}$ (Ip et al., 2009); $K_{\mathrm{H}, 298 \mathrm{~K}}$ (methylglyoxal) $=3.2 \times 10^{4} \mathrm{M} \mathrm{atm}^{-1}$ in sea water (Zhou and Mopper, 1990). For methylglyoxal, the Henry's law constant is significantly smaller in pure water $\left(2970 \mathrm{M} \mathrm{atm}^{-1}\right.$ at $298 \mathrm{~K}$, Betterton and Hoffmann, 1988), while ionic effects do not seem to significantly affect the constant for glyoxal. The assumption of cloud water being an ionic solution appears to be justified since it comprises many inorganic and organic compounds at micro- and up to tenths of millimolar concentrations. Small temperature fluctuations could also cause deviations in gas/aqueous phase partitioning due to the strong temperature dependence of the $K_{\mathrm{H}}^{*}$ values. While the aforementioned studies analysed bulk water samples, sizeresolved measurements have shown enhanced formaldehyde concentrations (by a factor of $\sim 1.5$ ) with decreasing droplet size. This trend has been explained by the kinetic limitation of formaldehyde uptake into larger droplets (Ervens et al., $2003 \mathrm{~b}$ ). While aqueous phase concentration of organic compounds with Henry's law constants $K_{\mathrm{H}}\left(^{*}\right)>1000 \mathrm{M} \mathrm{atm}^{-1}$ do not significantly deviate from those as predicted based on thermodynamic equilibrium, a significant enrichment of less soluble compounds $\left(K_{\mathrm{H}}(*)<1000 \mathrm{M} \mathrm{atm}^{-1}\right)$ has been observed in several studies (Valsaraj, 1988; van Pinxteren et al., 2005). The reasons for this deviation are not fully clear, but likely include adsorption on the air/water interface or colloid formation of these compounds (Valsaraj et al., 1993).

The fraction of aldehydes that is predicted to be present in the aqueous phase is shown in Fig. 4. It is evident that only for the highly soluble glyoxal the dissolved fraction might reach a maximum of $\sim 70 \%$ (at $L W C \geq 0.1 \mathrm{~g} \mathrm{~m}^{-3}$ ), whereas the dissolved fraction of the less soluble aldehydes does not exceed $10 \%$ at any reasonable LWC. While these aldehydes will (partially) evaporate during drop evaporation, their different reactivities in the gas and aqueous phases also impact the aldehyde budgets to different extents (cf. Sect. 1). Considering that there are several dark sources of $\mathrm{OH}$ in the aqueous phase (e.g., Fenton reactions, Ervens et al., 2003a) the ratio of the loss rates in the gas and aqueous phase will be even higher during early morning or evening when several of the fog and cloud samples were acquired. Thus, the aqueous phase does not only act as a reservoir for aldehydes and protects them from being photolyzed (R1-R6), but it also represents a significant sink for aldehydes due to the efficient consumption that affects the overall aldehyde budgets. 
In addition to hydration that is implicitly included in the effective Henry's law constants, aldehyde partitioning can be further shifted towards the aqueous phase by the formation of adducts with sulfur(IV) (Olson and Hoffmann, 1989):

$$
\mathrm{RCH}(\mathrm{OH})_{2}+\mathrm{HSO}_{3}^{-} \rightleftarrows \mathrm{RCH}(\mathrm{OH}) \mathrm{SO}_{3}^{-}
$$

The overall partitioning of aldehydes can be then calculated based on the equilibrium constants for (R7) for formaldehyde $\left(K_{\mathrm{SIV}, \mathrm{HCHO}}=3.6 \times 10^{6} \mathrm{M}^{-1}\right)$, glyoxal $\left(K_{\mathrm{SIV}, \mathrm{Gly}}=\right.$ $\left.2.8 \times 10^{4} \mathrm{M}^{-1}\right)$, and methylglyoxal $\left(K_{\mathrm{SIV}, \mathrm{Mgly}}=3.1 \times 10^{5}\right.$ $\mathrm{M}^{-1}$ ) (Olson and Hoffmann, 1989). Similar to the expression for an effective Henry's law constant that includes hydration (Betterton and Hoffmann, 1988), the partitioning of total aldehyde (aldehyde + hydrated aldehyde + sulfur(IV) adduct) can be expressed as

$K_{\mathrm{H}}^{\mathrm{SIV}}=\frac{\left[\mathrm{RCH}(\mathrm{OH})_{2}+\mathrm{RCH}(\mathrm{OH}) \mathrm{SO}_{3}^{-}\right]_{\mathrm{aq}}}{\mathrm{RCHO}(\mathrm{gas})}$

Similar to our definition of $K_{\mathrm{H}}^{* \mathrm{DOC}}$, this $K_{\mathrm{H}}^{\mathrm{SIV}}$ does not follow strictly the definition of a Henry's law constant as it includes chemical conversion in addition to hydration. Rearranging Eq. (4) and substituting

$$
\left[\mathrm{RCH}(\mathrm{OH}) \mathrm{SO}_{3}^{-}\right]=K_{\mathrm{SIV}, \mathrm{RCHO}} \cdot\left[\mathrm{RCH}(\mathrm{OH})_{2}\right] \cdot[\mathrm{S}(\mathrm{IV})]_{\mathrm{aq}}
$$

yields

$$
K_{\mathrm{H}}^{\mathrm{SIV}}=K_{\mathrm{H}, \mathrm{Hydr}} \times\left(1+K_{\mathrm{SIV}, \mathrm{RCHO}} \times[\mathrm{S}(\mathrm{IV})]_{\mathrm{aq}}\right)
$$

whereas $[\mathrm{S}(\mathrm{IV})]_{\mathrm{aq}}$ is the total $\left[\mathrm{HSO}_{3}^{-}+\mathrm{SO}_{3}^{2-}\right]$ concentration in the aqueous phase. Thus, a significant enhancement in aldehyde partitioning beyond that as suggested by $K_{\mathrm{H}}$ (including hydration) is only expected if $[\mathrm{S}(\mathrm{IV})]_{\mathrm{aq}} \gg$ $K_{\text {SIV,RCHO. }}$ Based on the average $\mathrm{SO}_{2}$ concentrations and $\mathrm{pH}$ values of the cloud/fog water in Whistler $\left(\mathrm{SO}_{2} \leq 0.3 \mathrm{ppb}\right.$; $\mathrm{pH} \sim 4.4)$, and from past measurements in Davis $\left(\mathrm{SO}_{2} \leq\right.$ $1 \mathrm{ppb}, \mathrm{pH} \sim 6$, Reilly et al., 2001), concentrations of [S(IV)] $\sim 4 \mu \mathrm{M}$ and $17 \mu \mathrm{M}$, respectively, can be calculated for the two locations. A comprehensive overview of sulfite measurements shows that only at very polluted locations, sulfite concentrations exceed $\sim 20 \mu \mathrm{M}$ and substantial sulfonate formation can be expected (Rao and Collett Jr., 1995). At all other locations, the fraction of formaldehyde that is present as hydroxy methanesulfonate is $<5 \%$. Since the $K_{\mathrm{SIV} \text {, RCHO for }}$ glyoxal and methylglyoxal are one and two orders of magnitude smaller, it can be concluded that (R7) does not significantly enhance aldehyde partitioning in the aqueous phase. In addition, it should be noted that Eq. (4) only accounts for equilibrium. However, it has been shown that the adduct formation is relatively slow (Betterton et al., 1988; Olson and Hoffmann, 1989) and only under very high S(IV) concentrations and in large droplets, deviations from thermodynamic equilibrium due to aldehyde-S(IV) interactions might be expected (Ervens et al., 2003b). Based on these estimates, sulfonate formation is not included in the following box model studies.

\section{Box model results}

\subsection{Predicted trends in aqueous phase concentrations of glyoxal and methylglyoxal}

Box model results are presented as a function of LWC and processing times. In order to cover the LWC range observed in the two field studies, multiple model simulations are performed with a constant LWC in each simulation. Different simulations cover a range of $0.05 \mathrm{~g} \mathrm{~m}^{-3}<\mathrm{LWC}<0.3 \mathrm{~g} \mathrm{~m}^{-3}$ whereas the observed ranges were $0.07 \mathrm{~g} \mathrm{~m}^{-3}<\mathrm{LWC}<0.15 \mathrm{~g} \mathrm{~m}^{-3}$ in Whistler and $0.05 \mathrm{~g} \mathrm{~m}^{-3}<\mathrm{LWC}<0.1 \mathrm{~g} \mathrm{~m}^{-3}$ in Davis (marked as horizontal grey lines in Fig. 5). While a cloud or fog event might last several hours, the lifetime of a single droplet is usually restricted to a few minutes upon which volatile gases, such as aldehydes, will evaporate together with water. Thus, the processing time of volatile aldehydes in the aqueous phase is mostly restricted to the drop lifetime bounded by formation/evaporation processes. While there is evidence that aldehydes do not completely evaporate from the condensed phase, high uncertainties exist in estimating the retained fraction in deliquesced particles (cf. Sect. 2.3.2).

A first set of model results shows the predicted aqueous phase concentrations for the three aldehydes (Fig. 5a-c, fh). Predicted formaldehyde concentrations are nearly identical for both locations with only a weak impact of processing time. Note that in the model, we do not consider any chemical sources of formaldehyde, but initialise it in the gas phase, constrained by corresponding measurements. Thus, unlike for glyoxal and methylglyoxal, there are no implicit uncertainties with its yields from precursors and formaldehyde can be considered as a "reference" compound whose concentration can be compared to the others. Predicted glyoxal concentrations are smaller by about one order of magnitude in the biogenic scenario as compared to the more anthropogenically-impacted location, in approximate agreement with observations at Whistler and Davis, respectively $(\sim 3 \mu \mathrm{M}$ vs. $\sim 0.5 \mu \mathrm{M}$; Fig. 3). Glyoxal and methylglyoxal concentrations in Whistler are generally somewhat underestimated as compared to the measurements. Beyond biases due to uncertainties in processing times, additional reasons might include uncertainties in aldehyde yields from gasphase oxidation of isoprene (Galloway et al., 2011). While the first-generation yields of glyoxal and methylglyoxal (as formed from aromatics) can be relatively well constrained, yields of higher generation products are less certain. Thus, predicted glyoxal and methylglyoxal levels might be biased low for isoprene. It should be also noted that the strong temperature-dependence of the aldehyde's Henry's law constants (decrease of $K_{\mathrm{H}}(T)$ by $\sim 30 \%$ per $1 \mathrm{~K}$ ) could also contribute to an underestimate of aqueous aldehyde levels. Predicted methylglyoxal concentrations differ by a factor of two between the two locations whereas glyoxal shows much greater variation (factor of $\sim 10$ ). Since both glyoxal 
and methylglyoxal concentrations are biased low, their ratio is similar to the observed ones, i.e., glyoxal/methylglyoxal ratios less than unity in Whistler (for $t>30 \mathrm{~min}$ ) and exceeding unity in Davis (Fig. 5d and i). These trends can be explained by the different yields of glyoxal and methylglyoxal by typical anthropogenic and biogenic precursors: The ratios of glyoxal to methylglyoxal molar yields in the gas phase as determined in chamber studies are greater than unity for toluene and p-xylene and slightly smaller than unity for other substituted monoaromatics (Nishino et al., 2010). Benzene is often one of the most abundant aromatic and only yields glyoxal. As it can be expected from these yields and their ratios, in anthropogenically influenced regions, the glyoxal/methylglyoxal ratios are near unity (Fu et al., 2008). Isoprene oxidation yields much higher methylglyoxal concentrations than glyoxal (Galloway et al., 2011) and, thus, in biogenically-impacted regions, the ratio of glyoxal to methylglyoxal is much smaller $(\sim 0.2)$ (Spaulding et al., 2003 ). Figure $5 \mathrm{e}$ and $\mathrm{j}$ show the ratio of the sum of glyoxal and methylglyoxal to formaldehyde and confirm that in less aged air masses the more soluble difunctional compounds have in total similar concentrations as formaldehyde, whereas they are much less abundant at more remote locations, in agreement with findings at many other locations (Fig. 3b).

In general, the predicted and observed aqueous phase concentrations of glyoxal and methylglyoxal in Whistler are much lower compared to other locations (Fig. 3b). Many recent model and laboratory studies have predicted efficient formation of secondary organic aerosol from glyoxal and methylglyoxal in the aqueous phase (Ervens et al., 2011 and references therein). For the relatively clean conditions in Whistler, mass concentrations of SOA on the order of $<10 \mathrm{ng} \mathrm{m}^{-3}$ are predicted upon processing times of several hours which exceeds the processing times as estimated here (results not shown). Such small changes in total aerosol mass might be below the detection limit. These results appear to be in contradiction to results from a recent laboratory study where efficient SOA formation in cloud water samples collected in Whistler was predicted (Lee et al., 2012), but they rather agree with findings of efficient organic aerosol oxidation by $\mathrm{OH}$ that leads to a decrease in total organic aerosol mass (Slowik et al., 2012). It should be noted that the study by Lee et al. (2012) was performed on highly concentrated aqueous samples under the influence of increased $\mathrm{OH}$ concentrations. Conditions of such high organic concentrations together with higher oxidant levels rather resemble aqueous aerosol (Tan et al., 2009; Ervens and Volkamer, 2010) and, thus, results from that study could be considered as processing in deliquesced particles. These experimental conditions might overestimate SOA formation for cloud conditions and do not reflect the limited time scales as encountered in cloud droplets that undergo quick formation and evaporation cycles. In summary, the box model applied here is able to qualitatively contrast concentration levels and ratios of the three aldehydes in the aqueous phase for the two different scenarios. This general agreement gives confidence that it is suited to conceptually simulate trends in concentration levels and ratios in the multiphase system despite uncertainties in initial conditions and details on cloud/fog microphysical parameters and evolution.

\subsection{Impact of aldehyde scavenging on $\mathrm{HO}_{2}$}

Gas phase photolysis of formaldehyde represents the major $\mathrm{HO}_{2}(\mathrm{~g})$ source and, thus, the initiator of the $\mathrm{HO}_{\mathrm{x}}$ cycle (R1). The photolysis rates of the different aldehydes in the gas phase differ by roughly a factor of four, with formaldehyde having the smallest and methylglyoxal having the largest value $\left(j_{\mathrm{HCHO}} \sim 4 \times 10^{-5} \mathrm{~s}^{-1} ; \mathrm{j}_{\text {Gly }} \sim 8 \times 10^{-5}\right.$ $\mathrm{s}^{-1} ; j_{\text {Mgly }} \sim 1.2 \times 10^{-4} \mathrm{~s}^{-1}$ for the photochemical conditions in Whistler). In order to predict the impact of aldehyde partitioning on $\mathrm{HO}_{2}$ gas phase concentrations in the presence and absence of clouds (fog), simulations are performed for a processing time of $30 \mathrm{~min}$ (as an average of processing time in fog and clouds, respectively) and LWC $=0.1 \mathrm{~g} \mathrm{~m}^{-3}$ which roughly represents a lower LWC limit in clouds and an upper limit for fog LWC (Fig. 1). Two sets of simulations are compared, i.e., one that considers a pure gas phase system without any partitioning to and processing in the aqueous phase whereas the second one uses the multiphase system as applied in Fig. 5.

Figure 6a shows that under mostly biogenic conditions (Whistler), $\mathrm{HO}_{2}(\mathrm{~g})$ levels can be reduced by up to two orders of magnitude $(-91 \%)$ in the presence of clouds. This difference is in general agreement with detailed multiphase model simulations that explored the effects of aqueous phase chemistry on organic peroxy radical levels (Herrmann et al., 2005). The decrease is smaller $(-76 \%)$ in more polluted conditions as encountered in Davis since the oxidation of $\mathrm{CO}$ is relatively more important in terms of $\mathrm{HO}_{2}$ production due to higher CO levels.

$\mathrm{CO}+\mathrm{OH}\left(+\mathrm{O}_{2}\right) \rightarrow \mathrm{CO}_{2}+\mathrm{HO}_{2}$

In addition, more complex chemical feedbacks are occurring that affect the oxidant cycles, such as the faster turnover of $\mathrm{OH}$ into $\mathrm{HO}_{2}$ due to the higher reaction rate of hydrated formaldehyde in the aqueous phase as compared to the corresponding gas phase process (Sect. 1).

In Fig. 6b, the reduction in $\mathrm{HO}_{2}(\mathrm{~g})$ concentration is shown whereas we define these changes as

$\left.\Delta \mathrm{HO}_{2}=\left(1-\frac{\mathrm{HO}_{2} \text { in the presence of aqueous phase }}{\mathrm{HO}_{2} \text { in the absence of aqueous phase }}\right) \cdot 100 \% 67\right)$

The bars on the left hand side of Fig. 6b ("base case") repeat the results of Fig. 6a. In order to investigate which aldehyde has the strongest impact on the $\mathrm{HO}_{2}$ decrease, three additional exploratory simulations were performed in which the uptake of a single aldehyde is excluded from the multiphase mechanism. These simulations allow us to understand 

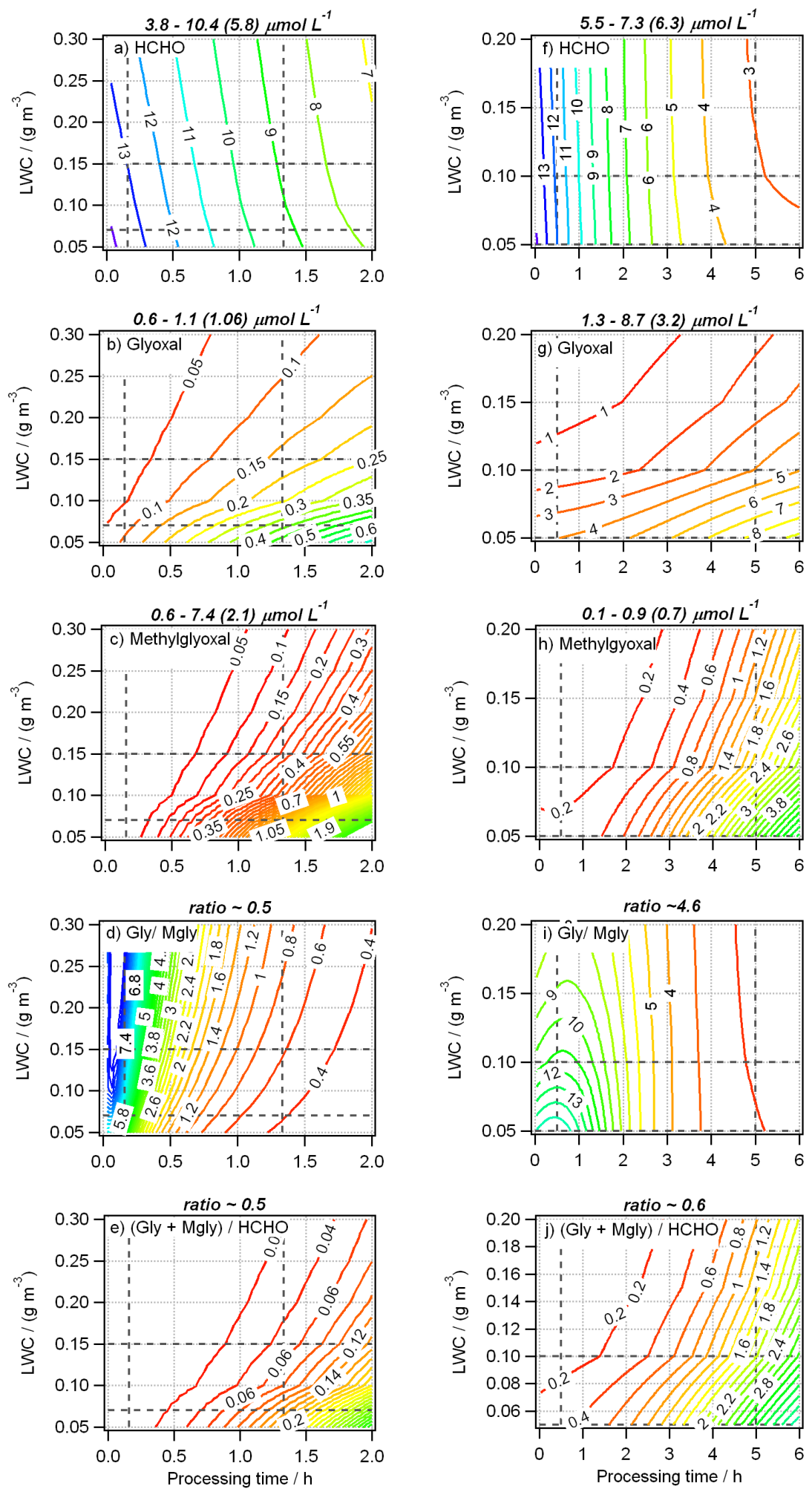

Fig. 5. Predicted concentrations and ratios of aldehydes $\left[\mathrm{mg} \mathrm{L}^{-1}\right]$ in the aqueous phase for the conditions in Whistler (left column) and Davis (right column) as a function of LWC and processing time. Processing times (vertical grey dashed lines) are bounded (i) in fog by settling times of droplets throughout the fog layer and (ii) in clouds as droplet lifetimes in different clouds and a multiple of this time if particles undergo several cloud cycles (cf. Sect. 2.3.2). Horizontal grey dashed lines show LWC ranges. (a, f) Formaldehyde; (b, g) Glyoxal; (c, h) Methylglyoxal; (d, i) Glyoxal/Methylglyoxal; (e, j), Ratio of sum of glyoxal and methylglyoxal to formaldehyde. Values on top of the figures denote (a-c; $\mathbf{f}-\mathbf{h})$ measured concentration ranges (average values in parentheses) and $(\mathbf{d}, \mathbf{e}, \mathbf{i}, \mathbf{j})$ ratios of average observed concentrations. 


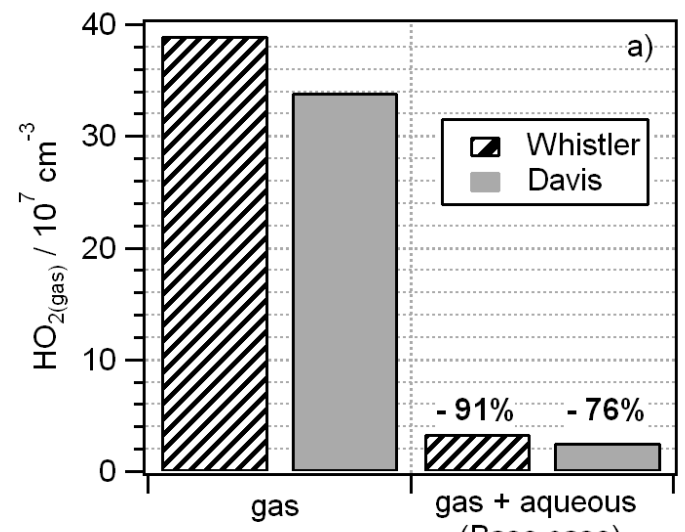

(Base case)

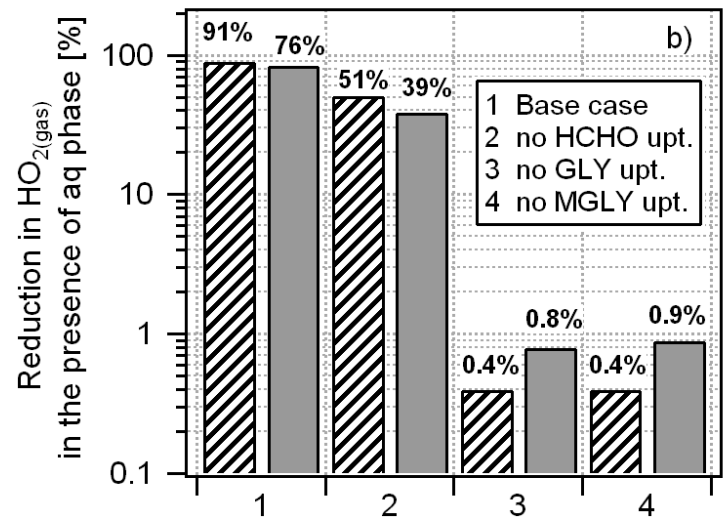

Fig. 6. Comparison of predicted $\mathrm{HO}_{2}$ (gas) concentrations in the presence and absence of an aqueous phase (a) Absolute $\mathrm{HO}_{2}(\mathrm{~g})$ concentration $\left[\mathrm{cm}^{-3}\right]$ for a pure gas phase system ("gas") and the multiphase system ("gas + aqueous", Base case) (b) Reduction of $\mathrm{HO}_{2}$ (g) [\%] (Eq. 7): "base case" refers to the simulations as in (a); the other three pairs of bars ("no HCHO, no GLY, no MGLY uptake", respectively) refer to exploratory simulations where the uptake of a single aldehyde (formaldehyde, glyoxal, methylglyoxal) into the aqueous phase is excluded from the chemical mechanism in the multiphase (gas + aqueous) system.

feedbacks in the multiphase system in a simplified manner. The results of these simulations are shown in the right hand part of Fig. 6b. Excluding the uptake of formaldehyde leads to $\mathrm{HO}_{2}(\mathrm{~g})$ concentrations that are $51 \%$ (Whistler) and $39 \%$ (Davis) smaller than in simulations that include its uptake and subsequent aqueous phase processing. The results from the other cases where the uptake of glyoxal or methylglyoxal are ignored show that the dissolution of either aldehyde only affects $\mathrm{HO}_{2}(\mathrm{~g})$ levels marginally $(<1 \%)$. Even though the fraction of glyoxal scavenged is the highest (Fig. 4), its relative role as $\mathrm{HO}_{2}(\mathrm{~g})$ precursor seems least important since its photolysis rate is roughly a factor of two smaller than that of methylglyoxal. It is not expected that the sum of the bars in the set of three simulations in Fig. $6 \mathrm{~b}$ add up to the total decreases as shown on the left-hand side since neglecting the uptake of a single aldehyde into the aqueous phase causes nonlinear feedbacks on oxidant concentration levels that impact oxidation rates in both phases. In general, these trends show that even though the aqueous phase is a more effective reservoir for the difunctional compounds (Fig. 4), their importance as $\mathrm{HO}_{2}$ precursor is much smaller due to their smaller gas phase concentrations and less efficient formation of $\mathrm{HO}_{2}(\mathrm{R} 3-\mathrm{R} 5)$. Our approach of using identical photolysis rates within and outside clouds might be somewhat simplified as within optically thick clouds photolysis rates tend to be lower, whereas they might be enhanced due to reflection on droplets in optically thinner regions of clouds, i.e., near their edges. The extent to which these opposite effects might possibly lead to a (partial) cancellation of the change in photolysis rates will depend on cloud properties (thickness, droplet size distributions, etc.). In addition to the cloud impacts on photolysis rates, it might be possible that gas phase aldehyde concentrations near cloud edges are enhanced from evaporating cloud droplets which might even enhance further $\mathrm{HO}_{2}$ production. For simplicity, these effects are not considered in our box model. However, it can be expected that they might affect the levels of all aldehydes to a similar extent and, thus, it is concluded that the trends in terms of the relative impacts of the different aldehydes on $\mathrm{HO}_{2}(\mathrm{~g})$ shown in Fig. 6 will not change.

These model results generally confirm conclusions by Lin et al. (2012) on the total $\mathrm{HO}_{\mathrm{x}}$ budget that have been drawn based on formaldehyde measurements: it was found that formaldehyde photolysis contributes $\sim 18 \%$ to the total $\mathrm{HO}_{\mathrm{x}}$ budget, only exceeded by $\mathrm{HONO}(67 \%)$ and followed by $\mathrm{O}_{3}$ photolysis and alkene reactions with ozone $(13 \%$ and $2 \%$, respectively). While these numbers are not directly comparable to our model results since we do not discuss any impacts on the $\mathrm{OH}$ budget, the fact that in the study by Lin et al. (2012) no other aldehydes were identified as significant contributors to the $\mathrm{HO}_{\mathrm{x}}$ budget is in agreement with our findings that glyoxal and methylglyoxal - as proxies for higher aldehydes - likely play a minor role.

Our model results suggest that the dissolution and subsequent hydration of aldehydes can significantly impact $\mathrm{HO}_{2}$ levels (reduction by nearly two orders of magnitude) and ultimately affect the oxidant cycles in the multiphase system. The estimated scavenged carbon fractions $(\sim 1 \%$ $<$ DOC/TOOC $<\sim 46 \%$ ) and the quantification of aldehydes as contributors to DOC ([formaldehyde + glyoxal + methylglyoxal $]_{\mathrm{aq}} /[\mathrm{DOC}] \sim 6 \%$ ) imply that even scavenging of a very small organic carbon fraction $(<1 \%)$ might lead to significant changes in the oxidant budget of the atmosphere. This fraction only represents the partitioning at a given time and for equilibrium conditions, but in the dynamical multiphase system, aldehydes are quickly consumed in the aqueous phase and, thus, affect the aldehyde levels in both the gas and aqueous phases. The extension of our study to difunctional aldehydes exceeds early findings on the role of clouds in impacting $\mathrm{HO}_{2}$ by removal of formaldehyde by aqueous phase processes (Lelieveld and Crutzen, 1991). Since the 
three aldehydes comprise only $\sim 6 \%$ of the total identified dissolved aldehydes in cloud and fog waters, it might be expected that the total effects of aldehyde hydration in the aqueous phase on $\mathrm{HO}_{2}$ levels could be even somewhat greater.

\section{Conclusions}

Dissolved organic carbon (DOC) and select carbonyl species were measured in clouds collected in Whistler (British Columbia, Canada) and fog in Davis (CA). Formaldehyde, glyoxal and methylglyoxal were present in the micromolar concentration range and accounted for up to $10 \%$ of the dissolved organic carbon. DOC concentrations were lower in Whistler compared to Davis and were consistent with literature data at similar locations. An overview of different datasets reveals that DOC as well as carbonyl concentrations increase from remote to polluted environments. The overall solubility (expressed here as an effective Henry's law constant $K_{\mathrm{H}}^{* \mathrm{DOC}}$ ) that describes the distribution of total organic carbon between the aqueous and gas phases shows an increase with increasing distance to biogenic or anthropogenic emission sources $\left(7000 \mathrm{M} \mathrm{atm}^{-1}<K_{\mathrm{H}}^{* \mathrm{DOC}}\right.$ $<71000 \mathrm{M} \mathrm{atm}^{-1}$ ). This trend points to a greater fraction of oxidised organic material and a higher partitioned organic carbon fraction in aged air masses. Indeed the aqueous phase carbon fraction increases from $\sim 2 \%$ in fresh air masses to $\sim 46 \%$ in more remote locations. In the gas phase, formaldehyde is the predominant aldehyde and its concentration exceeds those of glyoxal and methylglyoxal approximately by an order of magnitude. However, the solubility (Henry's law constant) of the difunctional compounds is greater by one and two orders of magnitude, respectively. Thus, difunctional compounds are more efficiently dissolved in the aqueous phase; it is predicted that at a liquid water content of $0.1 \mathrm{~g} \mathrm{~m}^{-3}, \sim 70 \%$ of glyoxal, $\sim 5 \%$ of methylglyoxal and $1 \%$ of formaldehyde are present in the aqueous phase. These different dissolved fractions of the aldehydes can explain similar concentration levels $(\sim \mu \mathrm{M})$ of these three aldehydes in the aqueous phase of fog and cloud droplets.

The formaldehyde, glyoxal and methylglyoxal concentration levels in cloud water as observed in Whistler and Davis can be reproduced reasonably well by box model simulations that are initialised with measured VOC precursor concentrations and liquid water contents and are performed over reasonable processing times estimated for cloud and fog conditions. Model results also show that the dissolution of formaldehyde has the greatest impact on predicted $\mathrm{HO}_{2}$ levels (reduction by nearly two orders of magnitude) despite its smallest dissolved fraction based on Henry's law constants. Since its oxidation in the aqueous phase is faster than it is in the gas phase, the continuous removal from the gas phase by consumption in the aqueous phase leads to an efficient decrease of the $\mathrm{HO}_{2}$ source. The contributions of more soluble glyoxal and methylglyoxal to the $\mathrm{HO}_{2}$ levels are marginal and only change predicted $\mathrm{HO}_{2}$ concentrations by $\sim 1 \%$ in total. Although the box model simulations performed in the present study might not be fully quantitative since the results depend on various conditions (e.g., drop distribution, liquid water content, processing time, impact of clouds on photolysis rates, etc.), it can be expected that the identified relative contributions to $\mathrm{HO}_{2}$ reductions from the three aldehydes will not be significantly different if more sophisticated models are used. In general, these studies suggest that a very small $(<1 \%)$ fraction of DOC might have significant impact on the oxidant levels in the atmospheric multiphase system.

\section{Supplementary material related to this article is available online at: http://www.atmos-chem-phys.net/13/ 5117/2013/acp-13-5117-2013-supplement.pdf.}

Acknowledgements. BE acknowledges support from NOAA's Climate Goal. We are grateful to James Hutchings and Aurelie Marcotte for their assistance with sampling during the fog and cloud field studies. We are grateful to Mike Mata, Qi Zhang and Cort Anastasio for their help with the Davis field work and Juniper Buller for helping with the Whistler field work. We appreciate useful discussions with Graham Feingold (NOAA/ESRL) and Jeff Collett (Colorado State University). Funding for the research was provided by National Science Foundation grants AGS0847710, AGS 0907261 and Environment Canada through the Clean Air Regulatory Agenda. The statements and conclusions in this paper are those of the authors and not necessarily those of NSF or Environment Canada. The mention of commercial products, their source, or their use in connection with material reported herein is not to be construed as actual or implied endorsement of such products.

Edited by: M. Kanakidou

\section{References}

Ahlm, L., Shakya, K. M., Russell, L. M., Schroder, J. C., Wong, J. P. S., Sjostedt, S. J., Hayden, K. L., Liggio, J., Wentzell, J. J. B., Wiebe, H. A., Mihele, C., Leaitch, W. R., and Macdonald, A. M.: Temperature-dependent accumulation mode particle and cloud nuclei concentrations from biogenic sources during WACS 2010, Atmos. Chem. Phys., 13, 3393-3407, doi:10.5194/acp-133393-2013, 2013.

Anastasio, C., Faust, B. C., and Allen, J. M.: Aqueous phase photochemical formation of hydrogen peroxide in authentic cloud waters, J. Geophys. Res., 99, 8231-8248, doi:10.1029/94jd00085, 1994.

Axson, J. L., Takahashi, K., De Haan, D. O., and Vaida, V.: Gas-phase water-mediated equilibrium between methylglyoxal and its geminal diol, P. Natl. Acad. Sci., 107, 6687-6692, doi:10.1073/pnas.0912121107, 2010.

Baboukas, E. D., Kanakidou, M., and Mihalopoulos, N.: Carboxylic acids in gas and particulate phase above the Atlantic Ocean, J. Geophys. Res., 105, 14459-14471, 2000. 
Bauer, H., Kasper-Giebl, A., Löflund, M., Giebl, H., Hitzenberger, R., Zibuschka, F., and Puxbaum, H.: The contribution of bacteria and fungal spores to the organic carbon content of cloud water, precipitation and aerosols, Atmospheric Research, 64, 109-119, doi:10.1016/s0169-8095(02)00084-4, 2002.

Betterton, E. A. and Hoffmann, M. R.: Henry's law constants of some environmentally important aldehydes, Environ. Sci. Technol., 22, 1415-1418, 1988.

Betterton, E. A., Erel, Y., and Hoffmann, M.: Aldehyde-Bisulfite Adducts: Prediction of Some of Their Thermodynamic and Kinetic Properties, Environ. Sci. Technol., 22, 92-99, 1988.

Blando, J. D. and Turpin, B. J.: Secondary organic aerosol formation in cloud and fog droplets: a literature evaluation of plausibilty, Atmos. Environ., 34, 1623-1632, 2000.

Brüggemann, E., Gnauk, T., Mertes, S., Acker, K., Auel, R., Wieprecht, W., Möller, D., Collett Jr., J. L., Chang, H., Galgon, D., Chemnitzer, R., Rüd, C., Junek, R., Wiedensohler, A., and Herrmann, H.: Schmücke hill cap cloud and valley stations aerosol characterisation during FEBUKO (I): Particle size distribution, mass, and main components, Atmos. Environ., 39, 42914303, doi:10.1016/j.atmosenv.2005.02.013, 2005.

Buxton, G. V., Malone, T. N., and Salmon, G. A.: Oxidation of glyoxal initiated by $\mathrm{OH}$ in oxygenated aqueous solutions, J. Chem. Soc. Faraday Trans., 93, 2889-2891, 1997.

Carrillo, J. H., Emert, S. E., Sherman, D. E., Herckes, P., and Collett, J. L.: An Economical Optical Cloud/Fog Detector, Atmos. Res., 87, 259-267, 2008.

Chameides, W. L.: The Photochemistry of a Remote Marine Stratiform Cloud, J. Geophys. Res., 89, 4739-4755, 1984.

Chow, J. C., Watson, J. G., Lowenthal, D. H., Chen, L. W. A., and Magliano, K. L.: Particulate carbon measurements in California's San Joaquin Valley, Chemosphere 62, 337-348, 2006.

Collett Jr., J. L., Herckes, P., Youngster, S., and Lee, T.: Processing of atmospheric organic matter by California radiation fogs, Atmos. Res., 87, 323-341, 2008.

Colvile, R. N., Choularton, T. W., Cape, J. N., Bandy, B. J., Bower, K. N., Burgess, R. A., Davies, T. J., Dollard, G. J., Gallagher, M. W., Hargreaves, K. J., Jones, B. M. R., Penkett, S. A., and Storeton-West, R. L.: Processing of oxidised nitrogen compounds by passage through winter-time orographic cloud, J. Atmos. Chem., 24, 211-239, doi:10.1007/bf00210284, 1996.

Demoz, B. B., Collett Jr., J. L., and Daube Jr., B. C.: On the Caltech Active Strand Cloudwater Collectors, Atmos. Res., 41, 47-62, doi:10.1016/0169-8095(95)00044-5, 1996.

Ehrenhauser, F. S., Khadapkar, K., Wang, Y., Hutchings, J. F., Delhomme, O., Kommalapati, R. R., Herckes, P., Wornat, M. J., and Valsaraj, K. T.: Processing of Atmospheric Polycyclic Aromatic Hydrocarbons by Fog in an Urban Environment, J. Environ. Monit., 14, 2566-2579, doi:10.1039/C2EM30336A, 2012.

Ervens, B. and Volkamer, R.: Glyoxal processing by aerosol multiphase chemistry: towards a kinetic modeling framework of secondary organic aerosol formation in aqueous particles, Atmos. Chem. Phys., 10, 8219-8244, doi:10.5194/acp-10-8219-2010, 2010.

Ervens, B., George, C., Williams, J. E., Buxton, G. V., Salmon, G. A., Bydder, M., Wilkinson, F., Dentener, F., Mirabel, P., Wolke, R., and Herrmann, H.: CAPRAM2.4 (MODAC mechanism): An extended and condensed tropospheric aqueous phase mechanism and its application, J. Geophys. Res., 108, 4426,
doi:10.1029/2002JD002202, 2003a.

Ervens, B., Herckes, P., Feingold, G., Lee, T., Collett, J. L. J., and Kreidenweis, S. M.: On the Drop-Size Dependence of Organic Acid and Formaldehyde Concentrations in Fog, J. Atmos. Chem., 46, 239-269, 2003b.

Ervens, B., Feingold, G., Frost, G. J., and Kreidenweis, S. M.: A modeling study of aqueous production of dicarboxylic acids, 1 . Chemical pathways and speciated organic mass production, J. Geophys. Res., 109, D15205, doi:10.1029/2003JD004387, 2004.

Ervens, B., Cubison, M. J., Andrews, E., Feingold, G., Ogren, J. A., Jimenez, J. L., DeCarlo, P., and Nenes, A.: Prediction of cloud condensation nucleus number concentration using measurements of aerosol size distributions and composition and light scattering enhancement due to humidity, J. Geophys. Res., 112, D10S32, doi:10.1029/2006JD007426, 2007.

Ervens, B., Turpin, B. J., and Weber, R. J.: Secondary organic aerosol formation in cloud droplets and aqueous particles (aqSOA): a review of laboratory, field and model studies, Atmos. Chem. Phys., 11, 11069-11102, doi:10.5194/acp-1111069-2011, 2011.

Finlayson-Pitts, B. J. and Pitts, J. N.: Chemistry of the upper and lower atmosphere, Academic Press, San Diego, California, 969 pp., 2000.

Fraser, M. P., Yue, Z. W., Tropp, R. J., Kohl, S. D., and Chow, J. C.: Molecular composition of organic fine particulate matter in Houston, Atmos. Environ., 36, 5751-5758, 2002.

Frost, G. J., Trainer, M., Mauldin III, R. L., Eisele, F. L., Prevot, A. S. H., Madronich, S., Kok, G., Schillawski, R. D., Baumgardner, D., and Bradshaw, J.: Photochemical modeling of OH levels during the First Aerosol Characterization Experiment (ACE 1), J. Geophys. Res., 104, 16041-16052, 1999.

Fu, T., Jacob, D. J., Wittrock, F., Burrows, J. P., Vrekoussis, M., and Henze, D. K.: Global budgets of atmospheric glyoxal, methylglyoxal, and implications for formation of secondary organic aerosol, J. Geophys. Res., 113, D15303, doi:10.1029/2007JD009505, 2008.

Fuzzi, S. and Zappoli, S.: The organic component of fog droplets, Proceedings of the 12th International Conference on Cloud and Precipitation, Zurich, Switzerland, 1996.

Galloway, M. M., Huisman, A. J., Yee, L. D., Chan, A. W. H., Loza, C. L., Seinfeld, J. H., and Keutsch, F. N.: Yields of oxidised volatile organic compounds during the $\mathrm{OH}$ radical initiated oxidation of isoprene, methyl vinyl ketone, and methacrolein under high- $\mathrm{NO}_{\mathrm{x}}$ conditions, Atmos. Chem. Phys., 11, 10779-10790, doi:10.5194/acp-11-10779-2011, 2011.

Gerber, H.: Direct measurement of suspended particulate volume concentration and far-infrared extinction coefficient with a laserdiffraction instrument, Appl. Opt., 30, 4824-4831, 1991.

Gong, W., Stroud, C., and Zhang, L.: Cloud Processing of Gases and Aerosols in Air Quality Modeling, Atmosphere, 2, 567-616, doi:10.3390/atmos2040567, 2011.

Guo, J., Wang, Y., Shen, X., Wang, Z., Lee, T., Wang, X., Li, P., Sun, M., Collett Jr., J. L., Wang, W., and Wang, T.: Characterization of cloud water chemistry at Mount Tai, China: Seasonal variation, anthropogenic impact, and cloud processing, Atmospheric Environment, 60, 467-476, doi:10.1016/j.atmosenv.2012.07.016, 2012.

Heald, C. L., Goldstein, A. H., Allan, J. D., Aiken, A. C., Apel, E., Atlas, E. L., Baker, A. K., Bates, T. S., Beyersdorf, A. J., 
Blake, D. R., Campos, T., Coe, H., Crounse, J. D., DeCarlo, P. F., de Gouw, J. A., Dunlea, E. J., Flocke, F. M., Fried, A., Goldan, P., Griffin, R. J., Herndon, S. C., Holloway, J. S., Holzinger, R., Jimenez, J. L., Junkermann, W., Kuster, W. C., Lewis, A. C., Meinardi, S., Millet, D. B., Onasch, T., Polidori, A., Quinn, P. K., Riemer, D. D., Roberts, J. M., Salcedo, D., Sive, B., Swanson, A. L., Talbot, R., Warneke, C., Weber, R. J., Weibring, P., Wennberg, P. O., Worsnop, D. R., Wittig, A. E., Zhang, R., Zheng, J., and Zheng, W.: Total observed organic carbon (TOOC) in the atmosphere: a synthesis of North American observations, Atmos. Chem. Phys., 8, 2007-2025, doi:10.5194/acp-8-20072008, 2008.

Healy, R. M., Wenger, J. C., Metzger, A., Duplissy, J., Kalberer, M., and Dommen, J.: Gas/particle partitioning of carbonyls in the photooxidation of isoprene and 1,3,5-trimethylbenzene, Atmos. Chem. Phys., 8, 3215-3230, doi:10.5194/acp-8-3215-2008, 2008.

Healy, R. M., Temime, B., Kuprovskyte, K., and Wenger, J. C.: Effect of Relative Humidity on Gas/Particle Partitioning and Aerosol Mass Yield in the Photooxidation of p-Xylene, Environ. Sci. Tech., 43, 1884-1889, doi:10.1021/es802404z, 2009.

Hennigan, C. J., Bergin, M. H., Russell, A. G., Nenes, A., and Weber, R. J.: Gas/particle partitioning of water-soluble organic aerosol in Atlanta, Atmos. Chem. Phys., 9, 3613-3628, doi:10.5194/acp-9-3613-2009, 2009.

Herckes, P., Lee, T., Trenary, L., Kang, G. U., Chang, H., and Collett, J. L.: Organic matter in San Joaquin Valley radiation fogs, Environ. Sci. Technol., 36, 4777-4782, 2002a.

Herckes, P., Hannigan, M. P., Trenary, L., Lee, T., and Collett, J. L.: The organic composition of radiation fog in Davis (California), Atmos. Res., 64, 99-108, 2002b.

Herckes, P., Chang, H., Lee, T., and Collett Jr., J. L.: Air pollution processing by radiation fogs, Water Air Soil Pollut., 181, 65-75, 2007.

Herrmann, H., Tilgner, A., Barzaghi, P., Majdik, Z., Gligorovski, S., Poulain, L., and Monod, A.: Towards a more detailed description of tropospheric aqueous phase organic chemistry: CAPRAM 3.0, Atmos. Environ, 39, 4351-4363, 2005.

Holets, S. and Swanson, R. N.: High-Inversion Fog Episodes in Central California, J. Appl. Meteorol., 20, 8, 890-899, doi:10.1175/1520-0450(1981)020;0890:hifeic ¿2.0.co;2, 1981.

Hutchings, J. W., Robinson, M. S., McIlwraith, H., Kingston, J. T., and Herckes, P.: The chemistry of intercepted clouds in Northern Arizona during the North American Monsoon Season, Water Air Soil Pollut., 199, 191-202, 2009.

Igawa, M., Munger, J. W., and Hoffmann, M. R.: Analysis of aldehydes in cloud- and fogwater samples by HPLC with a postcolumn reaction detector, Environ. Sci. Technol, 23, 556-561, 1989.

Ip, H. S. S., Huang, X. H. H., and Yu, J. Z.: Effective Henry's law constants of glyoxal, glyoxylic acid and glycolic acid, Geophys. Res. Lett., 36, L01802, doi:10.1029/2008GL036212, 2009.

Jacob, D. J., Waldman, J. M., Munger, J. W., and Hoffmann, M. R.: A field investigation of physical and chemical mechanisms affecting pollutant concentrations in fog droplets, Tellus B, 36B, 272-285, doi:10.1111/j.1600-0889.1984.tb00247.x, 1984.

Khare, P., Kumar, N., Kumari, K. M., and Srivastava, S. S.: Atmospheric Formic and Acetic Acids: An Overview, Rev. Geophys., 37, 227-248, 1999.
Khwaja, H. A., Brudnoy, S., and Husain, L.: Chemical Characterization of three summer cloud episodes at Whiteface Mountain, Chemosphere, 31, 3357-3381, 1995.

Leaitch, W. R., Lohmann, U., Russell, L. M., Garrett, T., Shantz, N. C., Toom-Sauntry, D., Strapp, J. W., Hayden, K. L., Marshall, J., Wolde, M., Worsnop, D. R., and Jayne, J. T.: Cloud albedo increase from carbonaceous aerosol, Atmos. Chem. Phys., 10, 7669-7684, doi:10.5194/acp-10-7669-2010, 2010.

Lee, A. K. Y., Herckes, P., Leaitch, W. R., Macdonald, A. M., and Abbatt, J. P. D.: Aqueous OH oxidation of ambient organic aerosol and cloud water organics: Formation of highly oxidised products, Geophys. Res. Lett., 38, L11805, doi:10.1029/2011g1047439, 2011.

Lee, A. K. Y., Hayden, K. L., Herckes, P., Leaitch, W. R., Liggio, J., Macdonald, A. M., and Abbatt, J. P. D.: Characterization of aerosol and cloud water at a mountain site during WACS 2010: secondary organic aerosol formation through oxidative cloud processing, Atmos. Chem. Phys., 12, 7103-7116, doi:10.5194/acp-12-7103-2012, 2012.

Lelieveld, J. and Crutzen, P. J.: The role of clouds in tropospheric photochemistry, J. Atmos. Chem., 12, 229-268, 1991.

Li, S.-M., Macdonald, A. M., Leithead, A., Leaitch, W. R., Gong, W., Anlauf, K. G., Toom-Sauntry, D., Hayden, K., Bottenheim, J., and Wang, D.: Investigation of carbonyls in cloud water during ICARTT, J. Geophys. Res., 113, D17206, doi:10.1029/2007JD009364, 2008.

Lim, Y. B., Tan, Y., Perri, M. J., Seitzinger, S. P., and Turpin, B. J.: Aqueous chemistry and its role in secondary organic aerosol (SOA) formation, Atmos. Chem. Phys., 10, 1052110539, doi:10.5194/acp-10-10521-2010, 2010.

Limbeck, A. and Puxbaum, H.: Dependence of in-cloud scavenging of polar organic aerosol compounds on the water solubility, J Geophys. Res., 105, 19857-19867, 2000.

Lin, Y. C., Schwab, J. J., Demerjian, K. L., Bae, M.-S., Chen, W.N., Sun, Y., Zhang, Q., Hung, H.-M., and Perry, J.: Summertime formaldehyde observations in New York City: Ambient levels, sources and its contribution to $\mathrm{HO}_{\mathrm{x}}$ radicals, J. Geophys. Res., 117, D08305, doi:10.1029/2011jd016504, 2012.

Liu, J., Zhang, X., Parker, E. T., Veres, P. R., Roberts, J. M., de Gouw, J. A., Hayes, P. L., Jimenez, J. L., Murphy, J. G., Ellis, R. A., Huey, L. G., and Weber, R. J.: On the gas-particle partitioning of soluble organic aerosol in two urban atmospheres with contrasting emissions: 2. Gas and particle phase formic acid, J. Geophys. Res.-Atmos., 117, D00V21, doi:10.1029/2012jd017912, 2012.

Loeflund, M., Kasper-Giebel, A., Schuster, B., Giebl, H., Hitzenberger, R., and Puxbaum, H.: Formic, Acetic, oxalic, malonic and succinic acid concentrations and their contribution to organic carbon in cloud water, Atmos. Environ., 26, 1553-1558, 2002.

Madronich, S. and Calvert, J. G.: Permutation reactions of organic peroxy radicals in the troposphere, J. Geophys. Res., 95, 56975715, 1990.

Maria, S. F. and Russell, L. M.: Organic and Inorganic Aerosol Below-Cloud Scavenging by Suburban New Jersey Precipitation, Environ. Sci. Technol., 39, 4793-4800, doi:10.1021/es0491679, 2005.

Maroń, M. K., Takahashi, K., Shoemaker, R. K., and Vaida, V.: Hydration of pyruvic acid to its geminaldiol, 2,2-dihydroxypropanoic acid, in a water-restricted 
environment, Chem. Phys. Lett., 513, 184-190, doi:10.1016/j.cplett.2011.07.090, 2011.

Matsumoto, K., Kawai, S., and Igawa, M.: Dominant factors controlling concentrations of aldehydes in rain, fog, dew water, and in the gas phase, Atmos. Environ., 39, 7321-7329, doi:10.1016/j.atmosenv.2005.09.009, 2005.

Matsunaga, S. N., Kato, S., Yoshino, A., Greenberg, J. P., Kajii, Y., and Guenther, A. B.: Gas-aerosol partitioning of semi volatile carbonyls in polluted atmosphere in Hachioji, Tokyo, Geophys. Res. Lett., 32, L11805, doi:10.1029/2004g1021893, 2005.

Mayer, B., Kylling, A., Madronich, S., and Seckmeyer, G.: Enhanced absorption of UV radiation due to multiple scattering in clouds: Experimental evidence and theoretical explanation, J. Geophys. Res., 103, 31241-31254, doi:10.1029/98jd02676, 1998.

Mo, R., Joe, P., Isaac, G. A., Gultepe, I., Rasmussen, R., Milbrandt, J., McTaggart-Cowan, R., Mailhot, J., Brugman, M., Smith, T., and Scott, B.: Mid-Mountain Clouds at Whistler During the Vancouver 2010 Winter Olympics and Paralympics, Pure Appl. Geophys., doi:10.1007/s00024-012-0540-2, 2012.

Monod, A., Poulain, L., Grubert, S., Voisin, D., and Wortham, H.: Kinetics of $\mathrm{OH}$-initiated oxidation of oxygenated organic compounds in the aqueous phase: new rate constants, structureactivity relationships and atmospheric implications, Atmos. Environ., 39, 7667-7688, 2005.

Morita, A., Kanaya, Y., and Francisco, J. S.: Uptake of the $\mathrm{HO}_{2}$ radical by water: Molecular dynamics calculations and their implications for atmospheric modeling, J. Geophys. Res., 109, D09201, doi:10.1029/2003jd004240, 2004.

Müller, K., van Pinxteren, D., Plewka, A., Svrcina, B., Kramberger, H., Hofmann, D., Bächmann, K., and Herrmann, H.: Aerosol characterisation at the FEBUKO upwind station Goldlauter (II): Detailed organic chemical characterisation, Atmos. Environ., 39, 4219-4231, doi:10.1016/j.atmosenv.2005.02.008, 2005.

Munger, J. W., Collett, J., Daube, B. C., and Hoffmann, M. R.: Carboxylic acids and carbonyl compounds in southern California clouds and fogs, Tellus B, 41B, 230-242, doi:10.1111/j.16000889.1989.tb00303.x, 1989.

Munger, J. W., Jacob, D. J., Daube , B. C., Horowitz, L. W., Keene, W. C., and Heikes, B. C.: Formaldehyde, glyoxal and methylglyoxal at a rural mountain site in central Virginia, J. Geophys. Res., 100, 9325-9333, 1995.

Ng, N. L., Canagaratna, M. R., Jimenez, J. L., Chhabra, P. S., Seinfeld, J. H., and Worsnop, D. R.: Changes in organic aerosol composition with aging inferred from aerosol mass spectra, Atmos. Chem. Phys., 11, 6465-6474, doi:10.5194/acp-11-64652011, 2011.

Nishino, N., Arey, J., and Atkinson, R.: Formation Yields of Glyoxal and Methylglyoxal from the Gas-Phase OH RadicalInitiated Reactions of Toluene, Xylenes, and Trimethylbenzenes as a Function of $\mathrm{NO}_{2}$ Concentration, J. Phys Chem. A, 114, 10140-10147, doi:10.1021/jp105112h, 2010.

Noone, K. J., Ogren, J. A., Hallberg, A., Heintzenberg, J., Ström, J., Hansson, H.-C., Svenningsson, B., Wiedensohler, A., Fuzzi, S., Facchini, M. C., Arends, B. G., and Berner, A.: Changes in aerosol size- and phase distributions due to physical and chemical processes in fog, Tellus B, 44, 489-504, doi:10.1034/j.16000889.1992.t01-4-00004.x, 1992.
Olson, T. M. and Hoffmann, M. R.: Hydroxyalkylsulfonate formation: its role as a S(IV) reservoir in atmospheric water droplets, Atmos. Environ., 23, 985-997, 1989.

Pierce, J. R., Leaitch, W. R., Liggio, J., Westervelt, D. M., Wainwright, C. D., Abbatt, J. P. D., Ahlm, L., Al-Basheer, W., Cziczo, D. J., Hayden, K. L., Lee, A. K. Y., Li, S.-M., Russell, L. M., Sjostedt, S. J., Strawbridge, K. B., Travis, M., Vlasenko, A., Wentzell, J. J. B., Wiebe, H. A., Wong, J. P. S., and Macdonald, A. M.: Nucleation and condensational growth to CCN sizes during a sustained pristine biogenic SOA event in a forested mountain valley, Atmos. Chem. Phys., 12, 3147-3163, doi:10.5194/acp-12-3147-2012, 2012.

Plum, C. N., Sanhueza, E., Atkinson, R., Carter, W. P. L., and Pitts, J. N., Jr.: OH radical rate constants and photolysis rates of “alpha”-dicarbonyls, Environ. Sci. Technol., 17, 479-484 1983.

Raja, S., Raghunathan, R., Yu, X.-Y., Lee, T., Chen, J., Kommalapati, R. R., Murugesan, K., Shen, X., Qingzhong, Y., Valsaraj, K. T., and Collett Jr., J. L.: Fog chemistry in the TexasLouisiana Gulf Coast corridor, Atmos. Environ., 42, 2048-2061, doi:10.1016/j.atmosenv.2007.12.004, 2008.

Raja, S., Raghunathan, R., Kommalapati, R. R., Shen, X., Collett Jr., J. L., and Valsaraj, K. T.: Organic Composition of Fogwater in the Texas-Louisiana Gulf Coast Corridor, Atmos. Environ., 43, 4214-4222, doi:10.1016/j.atmosenv.2009.05.029, 2009.

Rao, X. and Collett Jr., J. L.: Behavior of S(IV) and Formaldehyde in a Chemically Heterogeneous Cloud, Environ. Sci. Technol., 29, 1023-1031, doi:10.1021/es00004a024, 1995.

Reilly, J. E., Rattigan, O. V., Moore, K. M., Judd, C., Sherman, D. E., Dutkiewicz, V. A., Kreidenweis, S. M., Husain, L., and Collett, J. L.: Drop size dependent S(IV) oxidation in chemically heterogenous radiation fogs, Atmos. Environ., 35, 5717-5728, 2001.

Schaefer, T., Schindelka, J., Hoffmann, D., and Herrmann, H.: Laboratory Kinetic and Mechanistic Studies on the OH-Initiated Oxidation of Acetone in Aqueous Solution, J. Phys. Chem. A, 116, 6317-6326, doi:10.1021/jp2120753, 2012.

Schwab, J. J., Felton, H. D., and Demerjian, K. L.: Aerosol chemical composition in New York state from integrated filter samples: Urban/rural and seasonal contrasts, J. Geophys. Res., 109, D16S05, doi:10.1029/2003jd004078, 2004.

Seinfeld, J. H. and Pandis, S. N.: Atmospheric chemistry and physics, John Wiley \& Sons, New York, 1326 pp., 1998.

Slowik, J. G., Wong, J. P. S., and Abbatt, J. P. D.: Real-time, controlled $\mathrm{OH}$-initiated oxidation of biogenic secondary organic aerosol, Atmos. Chem. Phys., 12, 9775-9790, doi:10.5194/acp12-9775-2012, 2012.

Sorooshian, A., Brechtel, F. J., Ervens, B., Feingold, G., Varutbangkul, V., Bahreini, R., Murphy, S., Holloway, J. S., Atlas, E. L., Anlauf, K., Buzorius, G., Jonsson, H., Flagan, R. C., and Seinfeld, J. H.: Oxalic acid in clear and cloudy atmospheres: Analysis of data from International Consortium for Atmospheric Research on Transport and Transformation 2004, J. Geophys. Res., 111, D23S45, doi:10.1029/2005JD006880, 2006.

Spaulding, R. S., Schade, G. W., Goldstein, A. H., and Charles, M. J.: Characterization of secondary atmospheric photooxidation products: Evidence of biogenic and anthropogenic sources, J. Geophys. Res., 108, doi:10.1029/2002JD002478, 2003.

Straub, D. J., Hutchings, J. W., and Herckes, P.: Measurements of fog composition at a rural site, Atmospheric Environment, 47, 
195-205, doi:10.1016/j.atmosenv.2011.11.014, 2012.

Stroud, C., S. Madronich, Atlas, E., Ridley, B., Flocke, F., Weinheimer, A., Talbot, R., Fried, A., Wert, B., Shetter, R., Lefer, B., Coffey, M., Heickes, B., and Blake, D.: Photochemistry in the Arctic free troposphere: $\mathrm{NO}_{\mathrm{x}}$ budget and the role of odd nitrogen reservoir recycling, Atmos. Environ., 37, 3351-3364, 2003.

Tan, Y., Perri, M. J., Seitzinger, S. P., and Turpin, B. J.: Effects of Precursor Concentration and Acidic Sulfate in Aqueous Glyoxal-OH Radical Oxidation and Implications for Secondary Organic Aerosol, Environ. Sci. Technol., 43, 8105-8112, doi:10.1021/es901742f, 2009.

Tie, X., Madronich, S., Walters, S., Zhang, R., Rasch, P., and Collins, W.: Effects of clouds on photolysis and oxidants in the troposphere, J. Geophys. Res., 108, doi:10.1029/2003JD003659, 2003.

Valsaraj, K. T.: On the Physico-Chemical Aspects of Partitioning of Hydrophobic Non-Polar Organics at the Air-Water Interface, Chemosphere, 17, 875-887, 1988.

Valsaraj, K. T., Thoma, G. J., Reible, D. D., and Thibodeaux, L. J.: On the enrichment of hydrophobic organic compounds in fog droplets, Atmos. Environ. Part A. General Topics, 27, 203-210, doi:10.1016/0960-1686(93)90351-X, 1993.

van Pinxteren, D., Plewka, A., Hofmann, D., Müller, K., Kramberger, H., Svrinca, B., Bächmann, K., Jaeschke, W., Mertes, S., Collett, J. L., and Herrmann, H.: Schmücke hill cap cloud and valley stations aerosol characterisation during FEBUKO (II): Organic compounds, Atmos. Environ., 39, 4305-4320, 2005.

Volkamer, R., Ziemann, P. J., and Molina, M. J.: Secondary Organic Aerosol Formation from Acetylene $\left(\mathrm{C}_{2} \mathrm{H}_{2}\right)$ : seed effect on SOA yields due to organic photochemistry in the aerosol aqueous phase, Atmos. Chem. Phys., 9, 1907-1928, doi:10.5194/acp9-1907-2009, 2009.
Wang, Y., Guo, J., Wang, T., Ding, A., Gao, J., Zhou, Y., Collett Jr., J. L., and Wang, W.: Influence of regional pollution and sandstorms on the chemical composition of cloud/fog at the summit of Mt. Taishan in northern China, Atmos. Res., 99, 434-442, doi:10.1016/j.atmosres.2010.11.010, 2011.

Wang, Z., Wang, T., Guo, J., Gao, R., Xue, L., Zhang, J., Zhou, Y., Zhou, X., Zhang, Q., and Wang, W.: Formation of secondary organic carbon and cloud impact on carbonaceous aerosols at Mount Tai, North China, Atmos. Environ., 46, 516-527, doi:10.1016/j.atmosenv.2011.08.019, 2012.

Warneck, P.: Multi-phase chemistry of $\mathrm{C}_{2}$ and $\mathrm{C}_{3}$ organic compounds in the marine atmosphere, J. Atmos. Chem., 51, 119-159, 2005.

Yin, Y., Parker, D. J., and Carslaw, K. S.: Simulation of trace gas redistribution by convective clouds - Liquid phase processes, Atmos. Chem. Phys., 1, 19-36, doi:10.5194/acp-1-19-2001, 2001.

Youngster, S.: The Processing of Aerosol Particles and Soluble Trace Gases by Radiation Fogs in Fresno, California, Master Thesis, Department of Atmospheric Science, Colorado State University, Fort Collins, 128 pp., 2005.

Zhang, Q., Worsnop, D. R., Canagaratna, M. R., and Jimenez, J. L.: Hydrocarbon-like and oxygenated organic aerosols in Pittsburgh: insights into sources and processes of organic aerosols, Atmos. Chem. Phys., 5, 3289-3311, doi:10.5194/acp-5-32892005, 2005.

Zhou, X. and Mopper, K.: Apparent Partition Coefficients of 15 Carbonyl Compounds between Air and Seawater and between Air and Freshwater; Implications for Air-Sea Exchange, Environ. Sci. Technol., 24, 1864-1869, 1990. 